\title{
Growth of North-East Atlantic Cold-Water Coral Reefs and Mounds during the Holocene: A High Resolution U-Series and ${ }^{14} \mathrm{C}$ Chronology
}

\author{
Mélanie Douarin ${ }^{1}$, Mary Elliot ${ }^{1}$, Stephen R. Noble ${ }^{2}$, Daniel Sinclair ${ }^{3}$, Lea- \\ Anne Henry ${ }^{4}$, David Long ${ }^{5}$, Steven G. Moreton ${ }^{6}$,J. Murray Roberts ${ }^{4,7,8}$
}

1: School of Geosciences, The University of Edinburgh, Grant Institute, The King's

Buildings, West Mains Road, Edinburgh, Scotland, EH9 3JW, UK;

M.A.L.Douarin@sms.ed.ac.uk

2: NERC Isotope Geosciences Laboratory, British Geological Survey, Keyworth, Nottingham, England, NG12 5GG, UK

3: Marine Biogeochemistry \& Paleoceanography Group, Institute of Marine and Coastal Sciences, Rutgers University, 71 Dudley Road, New Brunswick, NJ 08901-8525, USA

4: Centre for Marine Biodiversity \& Biotechnology, School of Life Sciences, HeriotWatt University, Edinburgh, Scotland, EH14 4AS, UK

5: British Geological Survey, West Mains Road, Edinburgh, Scotland, EH9 3LA, UK

6: NERC Radiocarbon Facility (Environment), Scottish Enterprise Technology Park, Rankine Avenue, East Kilbride, Glasgow, Scotland, G75 0QF, UK

7: Scottish Association for Marine Science, Scottish Marine Institute, Oban, Argyll, PA37 1QA, UK

8: Center for Marine Science, University of North Carolina Wilmington, $601 \mathrm{~S}$. College Road, Wilmington, NC 28403-5928, USA

\section{Abstract}

We investigate the Holocene growth history of the Mingulay Reef Complex, a seascape of inshore cold-water coral reefs off western Scotland, using U-series dating of 34 downcore and radiocarbon dating of 21 superficial corals. Both chronologies reveal that the reef framework-forming scleractinian coral Lophelia pertusa shows episodic occurrence during the late Holocene. Downcore U-series dating revealed unprecedented reef growth rates of up to $12 \mathrm{~mm} \mathrm{a}^{-1}$ with a mean rate of $3-4 \mathrm{~mm} \mathrm{a}^{-1}$. Our study highlighted a persistent hiatus in coral occurrence from 1.4 ka to modern times despite present day conditions being conducive for coral growth. The growth history of the complex was punctuated at least twice by periods of reduced growth rates: $1.75-2.8 \mathrm{ka}, 3.2-3.6 \mathrm{ka}$ and to a lesser extent at $3.8-4 \mathrm{ka}$ and $4.2 \mathrm{ka}$. Timing of coral hiatuses and reduced reef growth rates at Mingulay were synchronous with those occurring across northern Europe. Our study suggests that large-scale shifts in 
palaeoenvironmental regimes associated with changes to the North Atlantic subpolar gyre may control these ecosystems.

\section{Introduction}

One of the most widespread cold-water corals is the reef framework-forming scleractinian Lophelia pertusa, which to date is known from all oceans except the Southern Ocean (Roberts et al., 2009). In the NE Atlantic, Lophelia occurs preferentially along the European continental margin (De Mol et al., 2002; Kenyon et al., 2003; Wheeler et al., 2007) where it is often associated with areas of positive topographic relief such as banks, seamounts and ridges likely due to favourable environmental conditions (e.g. hydrology, food supply, current strength; Davies et al., 2008). Local hydrodynamics are crucial for coral dispersal and recruitment, preventing corals from being smothered by sediments, and as a food supply mechanism for sessile suspension feeders such as corals (Genin et al., 1986; Frederiksen et al., 1992; White et al., 2005; Mienis et al., 2007; White, 2007; Davies et al., 2009; Mienis et al., 2009).

Some of the best-studied Lophelia reefs are those found on coral carbonate mounds that can grow hundreds of metres high and few kilometres long (Wheeler et al., 2007). Several models of coral carbonate mound ontogeny have been proposed to explain the initiation and development of such structures, which generally converge on the importance of a complex interaction between sediment accumulation and coldwater coral colonisation and growth under favourable environmental regimes (Henriet et al., 2001; De Mol et al., 2002; Dorschel, 2003; Roberts et al., 2006; Rüggeberg et al., 2007; Eisele et al., 2008; de Haas et al., 2008). The last $11 \mathrm{ka}$, as well as previous warm interglacial periods such as marine isotope stages (MIS) 5, 7 and 9, have been favourable for coral growth and thus coral carbonate mound development in the NE Atlantic between $50^{\circ} \mathrm{N}$ and $70^{\circ} \mathrm{N}$ (Frank et al., 2009; Douville et al., 2010; Frank et al., 2011). To date no Lophelia from glacial periods have been found at these latitudes in the NE Atlantic (Dorschel, 2003; Kenyon et al., 2003; Schröder-Ritzrau et al., 2003; Frank et al., 2004; Dorschel et al., 2007; Rüggeberg et al., 2007; Mienis et al., 2009), hence glacial conditions are assumed to be detrimental to the growth of individual coral colonies and thus to coral carbonate mounds at these latitudes (Kenyon et al., 2003; Frank et al., 2009; Frank et al., 2011). Interestingly, at lower 
latitudes (between $20^{\circ} \mathrm{N}$ and $50^{\circ} \mathrm{N}$ ) Lophelia pertusa reef growth is reported during cool events and glacial periods (such as the Younger Dryas and the MIS 2, 4, 6 and 8) in the Gulf of Cádiz, Mediterranean Sea and offshore Mauritania (Wienberg et al., 2009; McCulloch et al., 2010; Wienberg et al., 2010; Eisele et al., 2011; Frank et al., 2011). It has been suggested that the early Holocene northern migration of the polar front would have contributed not only to the restoration of optimal environmental conditions for L. pertusa occurrence (e.g. temperature, productivity, sedimentation processes) but also to coral dispersal from the Mediterranean to $70^{\circ} \mathrm{N}$ via the reestablishment of modern-like north Atlantic meridional overturning circulation (AMOC) (De mol, 2005; Pirlet et al., 2011; Frank et al., 2011; Henry et al., submitted). Thus, it could be hypothesised that relative changes in AMOC associated with North Atlantic subpolar gyre (SPG) dynamics have affected coral occurrence, growth and recruitment over the last $11 \mathrm{ka}$.

U-series dating of cold-water coral fragments from coral carbonate mounds on the European continental margin allows quantification of the vertical mound growth rate (VMGR), a method that reveals periods of mound build-up coupled to palaeoceanographic changes (Frank et al., 2009). Because coral framework acts as a sediment trap for both laterally and vertically advected sediment flux, the VMGR is consistently higher during conditions favourable for coral growth. Such conditions are met when local hydrodynamics facilitate repeated coral recruitment events that form eventually coalesce to form large reef frameworks (Genin et al., 1986; Frederiksen et al., 1992; White et al., 2005; Mienis et al., 2007; White, 2007; Davies et al., 2009; Mienis et al., 2009; Frank et al., 2009; Frank et al., 2011; Douarin et al., in review; Henry et al., submitted).

Since cold-water coral mounds and continental shelves are both frequently characterized by high growth and sedimentation rates, it is assumed that shallow inner-shelf cold-water coral reefs may have especially high growth rates. Sediment cores through these structures could therefore offer the potential for high-resolution palaeoenvironmental reconstructions. Cold-water coral reefs occur on the British continental shelf in the Sea of Hebrides (also known as The Minch), 13 kilometres east of the island of Mingulay (Figure 1) (Roberts et al., 2005).Vibrocores containing mixed sediment/coral fragments were taken through the Mingulay Reef Complex in 2007 by the British Geological Survey. These cores are the subjects of the research 
presented here. The aims of the present study are to: 1) define the spatial and temporal evolution of Mingulay Reef Complex, 2) estimate and compare NE Atlantic Lophelia occurrence and reef/mound growth during the Holocene, and 3) establish whether large-scale shifts in palaeoenvironmental regimes have controlled coral occurrence and reef/mound growth during the Holocene.

\section{Cold-water coral sampling}

\subsection{Vibrocores}

Corals from two vibrocores on the Minguay Reef Complex were studied. The cores $+56-08 / 929 \mathrm{VE}$ and $+56-08 / 930 \mathrm{VE}$ (hereafter referred to as cores 929 and 930) were collected in October 2007 by the British Geological Survey during a survey on board the NERC vessel the RRS James Cook Cruise 015 (Stewart and Gatliff, 2008) (Table 1 and Figure 2).

Because the cores contained coral fragments embedded in sediment they were frozen prior to splitting to avoid disrupting the position and orientation of the coral fragments and to preserve the core's internal sedimentary structure. While frozen, the cores were split using a diamond bladed circular rock-cutting saw. To avoid any potential contamination from the cutting fluid, the uppermost surfaces of both halves were immediately removed. Once opened and defrosted, the cores were dissected at 1 $\mathrm{cm}$ intervals, documenting the position and state of preservation of each coral fragment within the cores and archiving the sediment and coral fragments.

\subsection{Surface sample locations}

Surface video-grab samples of coral rubble were taken from random locations at three reefs (Mingulay Reef 1, Mingulay Reef 5 North, and Banana Reef) during cruises on the research vessels MY Esperanza (2005), RRS Discovery Cruises 340b and 367 (2009 and 2011, respectively) and RV Calanus (2010). Three other surface samples were taken from the top of cores collected by the 2007 BGS cruise. Surface sample information is detailed in Figure 2 and Table 3.

\subsection{Hydrological setting}

Waters of Atlantic origin occupy the outer parts of the continental self and the deeper (>100 m) coastal waters of west Scotland (Craig, 1959; Hill et al., 1997; Inall 
et al., 2009). At the surface the Scottish Coastal Current (SCC) brings northward colder and fresher waters from the Irish and Clyde Seas (Ellett and Edwards, 1983). Today Lophelia pertusa reefs from the Mingulay Reef Complex are restricted to this Atlantic-origin water (Dodds et al., 2007) where strong SW-NE currents enhance the food supply within the area (Davies et al., 2009).

The Norwegian coral/sediment cores considered for this study were retrieved from Sjternsund (262 m) and Trænadjupet (315 m; López Correa et al., 2012). These two sites are bathed in North Atlantic Current (NAC) waters. The surface waters of the Norwegian shelf are characterised by the fresher Norwegian Coastal Current (NCC).

The NAC follows the boundary between the SPG waters (fresher and cooler) and the subtropical gyre (STG; warmer and saltier) (Hátún et al., 2005). The NAC strength, direction and composition respond to SPG dynamics (Hátún et al., 2005): when the SPG circulation is stronger and presents a more pronounced east-west shape the SPG waters influence relative to the STG waters to the NAC is increased. Conversely, when the SPG circulation is weak and forms a more pronounced northsouth shape, a lower contribution of the SPG waters relative to the STG waters to the coral sites would be observed.

Cold-water corals from Rockall Bank (core MD 01-2454G, 747 m water depth) and Porcupine Seabight (MD 01-2459G, $610 \mathrm{~m}$ water depth) coral/sediment cores dated by Frank et al., 2009 and analysed by Colin et al. (2012) and Copard et al. (2012) for neodymium isotopic composition $(\varepsilon \mathrm{Nd})$ are influenced by intermediate water masses. The relative contributions of the water masses at the coral sites are also directly influenced by the SPG dynamics (Colin et al., 2010). The relatively homogenous Atlantic water flowing through Rockall Trough (Holliday, 2003), is formed by a mixture of SPG water, the Subpolar Mode Water (SPMW) (Lacan and Jeandel, 2004) and water originating in the STG: the saline Eastern North Atlantic Water (ENAW) and the saline and warm North Atlantic Central Water (NACW) (Piepgras and Wasserburg, 1987; Copard et al., 2010). The SPMW itself results from mixing of warm, saline NACW with relatively fresh, cold Sub-Arctic Intermediate Water (SAIW) (Piepgras and Wasserburg, 1987; Lacan and Jeandel, 2004). 
Finally, it is important to note that the northward flow of Mediterranean Outflow Water (MOW) and its influence at the different coral sites remains a matter of debate. Hydrological evidences suggest that MOW would flow to the Porcupine Seabight (Holliday et al., 2000). However, in Rockall only episodic MOW influence would occur when the eastward extension of the SPG is reduced (Lozier and Stewart, 2008). Genetic work carried out on live Lophelia pertusa from the Mediterranean Sea, Rockall Bank, Porcupine Seabight and Norway supports this interpretation (Henry et al., submitted). The degree of genetic similarity suggests that coral larvae from the Mediterranean Sea are transported to the British Isles through the action of MOW (Henry et al., submitted). However, corals from Norway, present more similarities with the British Isles implying that coral dispersal northward to the Norwegian Sea is not directly associated with the MOW inflow (Henry et al., submitted).

\section{Methods}

Coral samples were dated using two methods. The downcore samples were dated by U-series and the surface samples were radiocarbon dated.

\subsection{Sample preparation}

Before dating, only relatively pristine corals were selected and ultrasonically cleaned in distilled water to avoid contamination from sediments and surface deposits. Inner and outer surfaces of corals were mechanically removed using a DREMEL tool until samples appeared completely clean under a binocular microscope, in order to remove contamination from iron and manganese oxides/hydroxides and surface sample re-crystallization of aragonite into calcite. Following physical removal of the surfaces, the samples were leached with hydrochloric acid $(0.1 \mathrm{~N})$ and rinsed three times with MilliQ water (e.g. Schröder-Ritzrau et al., 2003).

Once cleaned, a piece of each coral fragment was powdered using an agate mortar and pestle and screened by XRD at the University of Edinburgh for aragonite content and purity. Radiocarbon and U-series analyses were undertaken on fragments with $>99 \%$ aragonite content.

\subsection{U-series dating}


$\mathrm{U}$ and Th chemical separation and mass spectrometry were carried out at the NERC Isotope Geosciences Laboratory (NIGL), British Geological Survey, Keyworth. Samples were ultrasonicated in dilute $\mathrm{HNO}_{3}$ and MilliQ water before dissolution in $15 \mathrm{M} \mathrm{HNO}_{3}$. Dissolved samples were spiked with a mixed ${ }^{229} \mathrm{Th}^{236} \mathrm{U}$ tracer calibrated against gravimetric solutions prepared from CRM 112a U metal and Ames Laboratory high purity Th metal. All acids were prepared by double subboiling-distillation starting with RomilSpA grade stock. Pre-concentration by Fe coprecipitation prior to $\mathrm{U}-\mathrm{Th}$ separation used a $\mathrm{Fe}$ in $1 \mathrm{M} \mathrm{HCl}$ solution prepared from Puratronic Fe nitrate and the initial chemical separation of $U$ and Th on $0.6 \mathrm{ml}$ columns using AG-1 x 8 anion resin followed procedures established by Edwards et al. (1988). Separated Th aliquots were further purified using a second pass through AG-1 x 8 columns, while separated U was purified on UTEVA columns following Andersen et al. (2008). Pilot $U$ isotope data were obtained on a Thermo Triton thermal ionization mass spectrometer (TIMS) employing a Mascom SEM and RPQ. $\mathrm{U}$ was loaded as a nitrate on double zone-refined Re filament assemblies. Mass bias was monitored via replicate CRM 112a analyses, and SEM gain was corrected during sample analysis using ${ }^{235} \mathrm{U} /{ }^{236} \mathrm{U}$ measured sequentially on static SEM/Faraday and Faraday/Faraday detectors. Corresponding Th data were obtained on a $\mathrm{Nu}$ instruments NuHRmulticollector inductively coupled mass spectrometer (MC-ICP-MS). The bulk of the $\mathrm{U}$ and $\mathrm{Th}$ data for this study, however, were obtained on a latterly acquired Thermo Neptune Plus MC-ICP-MS. Samples were introduced with an Aridus II desolvating nebulizer in $0.2 \mathrm{M} \mathrm{HCl}-0.05 \mathrm{M} \mathrm{HF}$, while sample washout used sequential $0.25 \mathrm{M} \mathrm{HCl}-0.1 \mathrm{M} \mathrm{HF}$ and $0.2 \mathrm{M} \mathrm{HCl}-0.05 \mathrm{M} \mathrm{HF}$ following Andersen et al. (2008). U mass bias and SEM/Faraday gain correction of unknowns was based on standard bracketing; exponential correction for $U$ mass bias was determined by analysis of CRM 112a spiked with a ${ }^{233} \mathrm{U} /{ }^{236} \mathrm{U}$ tracer (IRMM 3636), while SEM gain was monitored using the static SEM/Faraday measurement of ${ }^{234} U /{ }^{235} \mathrm{U}$ on mass biascorrected unspiked CRM 112a data. On peak zero, hydride and tailing corrections followed Heiss et al. (2013).Accuracy (within 0.1\%) and reproducibility (within $0.2 \%$ ) were monitored by replicate ${ }^{234} \mathrm{U} /{ }^{238} \mathrm{U}$ analyses of Harwell uraninite HU-1. Mass bias and SEM gain for Th measurements were corrected using an in-house ${ }^{229} \mathrm{Th}^{230}{ }^{23 h}-{ }^{232} \mathrm{Th}$ reference solution calibrated by ICP-MS against CRM 112a. Total ${ }^{238} \mathrm{U}$ and ${ }^{232}$ Th blanks were $<10 \mathrm{pg}$ and $<4 \mathrm{pg}$, respectively, during this study and were negligible relative to the sample $U$ and Th. Data were reduced using an in-house 
Excel spreadsheet and ages calculated with Isoplot version 3 add-in (Ludwig, 2003a) following Ludwig (2003b) using the decay constants of Cheng et al. (2000). Correction for ${ }^{230} \mathrm{Th}$ from seawater followed Frank et al. (2005) $\left(\left[{ }^{230} \mathrm{Th} /{ }^{232} \mathrm{Th}\right]=10 \pm\right.$ 4). Quoted uncertainties (Table 2) for activity ratios, initial $\delta^{234} U{ }^{238} U$, and age are at the 2 sigma level. These include a c. $0.2 \%$ uncertainty estimated for the combined ${ }^{236} \mathrm{U} /{ }^{229} \mathrm{Th}$ tracer calibration uncertainty and measurement reproducibility of reference materials (HU-1, CRM 112a, in-house Th reference solution) as well as the propagated uncertainties from the seawater Th correction and measured isotope ratio uncertainty.

\subsection{Radiocarbon dating}

Nineteen surface Lophelia fragments were prepared to graphite at the NERC Radiocarbon Facility (East Kilbride). The samples were chemically etched to remove the outer $20 \%$ (by weight) of each coral fragment by controlled hydrolysis using 0.02 $\mathrm{M} \mathrm{HCl}$. The samples were rinsed, dried and homogenised. A known weight of the pretreated sample was hydrolysed to $\mathrm{CO}_{2}$ using $85 \%$ orthophosphoric acid $\left(\mathrm{H}_{3} \mathrm{PO}_{4}\right)$ at room temperature. An aliquot of $\mathrm{CO}_{2}$ from each sample was taken to measure $\delta^{13} \mathrm{C}$ (Table 3) on a dual inlet stable isotope mass spectrometer (VG OPTIMA) and is representative of $\delta^{13} \mathrm{C}$ in the original, pre-treated sample material. The remaining $\mathrm{CO}_{2}$ was converted to graphite by a two-stage reduction over heated Fe and $\mathrm{Zn}$ (Slota et al., 1987).

The ${ }^{14} \mathrm{C}$ in the samples was measured at the Scottish Universities Environmental Research Centre (SUERC) AMS Laboratory and corrected to $\delta^{13} \mathrm{C}_{\mathrm{VPDB}} \%$ - 25 using $\delta^{13} \mathrm{C}$ values provided in Table 3 . Results are reported as conventional radiocarbon years $\mathrm{BP}$ (relative to $\mathrm{AD} 1950$ ) at the $\pm 2 \sigma$ level for overall analytical confidence and as calibrated age-ranges using the OxCal 4.1 calibration software (Bronk Ramsey, 2009)with the Marine 09 dataset (Reimer et al., 2009). A local marine reservoir correction $(\Delta \mathrm{R})$ of 0 was applied to sample ages $<1 \mathrm{ka}$, in line with the findings of Harkness (1983) and samples with older ages were corrected using $\Delta \mathrm{R}=-79 \pm 17$ years as per Ascough et al. (2004).

\section{Results}

\subsection{U-series chronology}


The downcore U-series dates acquired for this study are displayed in (Table 2)Error! Reference source not found.. Mingulay corals contained between $2.8-3.8$ ppm of uranium. A total of 13 and 21 U-series dates were obtained from cores 929 and 930, respectively. These data permit the construction of age/depth profiles for the two cores (Figure 3).

The $\delta^{234} \mathrm{U}_{\text {inital }}$ values of the samples considered in this study ranged from 142.9 $\pm 2.4 \%$ to $150.0 \pm 3.5 \%$ ( $2 \sigma$ uncertainties). These values are indistinguishable from published $\delta^{234} U$ values of seawater (149.6\% $\pm 3 \%$ o $1 \mathrm{SD}, \mathrm{n}=23$; Delanghe et al., 2002 or $146.6 \% \pm 2.5 \%$ 1se; Robinson et al., 2004) and are close to modern cold-water coral values from the Pacific, Atlantic, Indian and Southern Oceans sampled from various water depths $(145.5 \pm 2.3 \%$, $2 \sigma, \mathrm{n}=20$; Cheng et al. $2000 \mathrm{a}) .{ }^{232} \mathrm{Th}$ values for all corals (Table 2Error! Reference source not found.) were relatively low at $<0.48 \pm$ $0.07 \mathrm{ppb}$, supporting the notion that most of the corals analysed here are primarily aragonitic (Frank et al., 2004). Finally, one coral fragment collected alive within the complex was dated in duplicate, with measured ages of $22 \pm 13$ a and $21 \pm 5$ a. Assuming the growth rate of an individual coral is $15-17 \mathrm{~mm} \mathrm{a}^{-1}$ (Orejas et al., 2008), and that the uppermost calices were removed during the cleaning procedure, the 1 to $2 \mathrm{~cm}$ of the coral fragments analyzed provide very accurate and reproducible ages giving us confidence in our fossil data.

After screening by $\delta^{234} U$ values, six dates were out of stratigraphic sequence (samples 6, 22, 28, 30, 31, 33; Table 2). Three hypotheses could explain this issue: 1). collapsing and mixing of coral fragments from the same colony, 2) older material from adjacent reefs has been reworked and transported to the actively accumulating reef site, or 3) entrainment of young coral fragments into the deeper core section (de Haas et al., 2008, Frank et al., 2009). Samples 22, 31 and 33 were significantly older than would be interpolated from the U-series age/depth relationship (Figure 3). This indicates potential reworking and transport of older material from an adjacent reef. The base of the reef (the last $100 \mathrm{~cm}$ of core 930) includes two age reversals toward older ages indicating that at the early stages of coral reef growth the height of the reef would allow more frequent transport of older material. These ages were not included in our growth rate estimations. Samples 6, 28 and 30 present significantly younger ages given the U-series age/depth relationship implying that the younger material may have become entrained during sampling. Note that two samples (27 and 29) from the 
same stratigraphic layer as samples 28 and 30 present ages in agreement with the stratigraphic sequence. Thus, we have only considered sample 28 and 30 for the rest of our study.

\subsection{Mingulay Complex growth rates}

Sufficient reliable high-resolution U-series data were acquired to characterise cold-water coral reef growth. With the exception of a few age inversions, $80 \%$ of the coral fragments present along the cores from the Mingulay Reef Complex were in stratigraphic order.

All fragments dated in this study were mid to late Holocene. The stratigraphic model of core 929 exhibited ages from 3.41 to $4.29 \mathrm{ka}$ and between 1.75 and $3.64 \mathrm{ka}$ for core 930. The oldest Lophelia pertusa fragment aging $7.68 \mathrm{ka}$ was measured from one out of stratigraphic order sample in core 930 . Core 929 had a vertical growth rate averaging $4 \mathrm{~mm} \mathrm{a}^{-1}$, although this varied between 0.5 and $12 \mathrm{~mm} \mathrm{a}^{-1}$ (Figure 3). Three major peaks in growth rate are centred at 3.7, 4, and $4.2 \mathrm{ka}$, and would reflect a local high reef expansion. The spike in growth rate reaching $19.5 \mathrm{~mm} \mathrm{a}^{-1}$ was estimated from one U-series age presenting an error of $0.1 \mathrm{a}$, therefore, it is possible that this value was slightly overestimated. Core 930 showed an average growth rate of $3 \mathrm{~mm} \mathrm{a}^{-}$ , ranging from 0.6 to $10 \mathrm{~mm} \mathrm{a}^{-1}$ (Figure 3 ).

Two major reductions in growth rate $\left(<2 \mathrm{~mm} \mathrm{a}^{-1}\right)$ were observed at $1.75-2.8$ $\mathrm{ka}$ and $3.2-3.6 \mathrm{ka}$. Two minor reductions were noted in core 929 at $3.8-4 \mathrm{ka}$ and at $\sim 4.2 \mathrm{ka}$. The growth rate decline at $\sim 3.5 \mathrm{ka}$ was recorded in both cores, suggesting that coral growth was affected over a wide portion of the reef complex.

\subsection{Radiocarbon chronology}

The age of the core tops (1.7 ka and $3.5 \mathrm{ka}$ ) are close to previously published radiocarbon dates from the surface of Mingulay Reef 1 and Mingulay Reef 5 (North), $3.54 \pm 0.06$ to $3.86 \pm 0.03 \mathrm{ka} \mathrm{BP}$, respectively (Roberts et al., 2005). These samples revealed that dead coral rubble found adjacent to living corals was much older than anticipated. Data from the 19 surface corals suggest that all samples are late Holocene $(0-4.2 \mathrm{ka}$; Table 3 and Figure 4$)$. The ages of dead coral spread more or less evenly across the period from 1.4 to $4 \mathrm{ka}$ with some evidence for clusters of ages 1.41 to 2.05 $\mathrm{ka}, 2.77 \mathrm{ka}, 3.16$ to $3.25 \mathrm{ka}, 3.6 \mathrm{ka}, 3.8$ to $4 \mathrm{ka}$ and $4.2 \mathrm{ka}$. This could indicate mortality events or a reduction in reef growth. Most importantly the absence of any 
dead coral dated between modern and $1.4 \mathrm{ka}$ strongly suggests that Mingulay reef growth was significantly disrupted after 1.4 ka ago.

\section{Discussion}

\subsection{Holocene reef growth rates}

Our data can be compared with other intensively dated coral-bearing sediment cores from the NE Atlantic between $50-70^{\circ} \mathrm{N}$ (Frank et al., 2009; López Correa et al., 2012; Figure 5). We chose to only consider L. pertusa dating in light of the probability that each cold-water coral species has specific environmental requirements.

The most intensively dated coral/sediment cores from mounds on the Celtic margin are cores MD 01-2454G from Rockall Bank and MD 01-2459G from the Porcupine Seabight (Frank et al., 2009). U-series dating revealed a VMGR from about 0.05 to $2.2 \mathrm{~mm} . \mathrm{a}^{-1}$ with values on average $\sim 0.2 \mathrm{~mm} \cdot \mathrm{a}^{-1}$ (Frank et al., 2009). By comparison, Holocene growth at Mingulay was on average 15 to 20 times greater (Figure 5). The lower resolution of the dating around one U/Th date every 450 years from the Celtic Margin cores (MD 01-2454G and MD 01-2459G) might have averaged out some of the peaks in growth rates, but probably not enough to explain the difference in VMGR with the Mingulay cores, which have on average one date every $100 \mathrm{a}$.

'Single generation' cold-water coral reefs (such as those within the Mingulay Reef Complex) are distinguished from larger 'coral carbonate mounds' in that they result from single intervals of growth rather than from multiple periods of reef growth (e.g. during interglacials) with periods of intervening sedimentation (e.g. during glacials; Roberts et al., 2006, 2009). Within the NE Atlantic, most single generation Holocene-age cold-water coral reefs reported to date are from the Norwegian continental shelf and fjords. The best studied sites so far are Fugløy Reef, Sternsund, Trænadjupet, Sula Ridge and Oslofjord (Hovland et al., 1998; Lindberg and Mienert, 2005; Lindberg et al., 2007; López Correa et al., 2012). The first estimates of growth rates from reefs on the Sula Ridge were about $2-3 \mathrm{~mm} \mathrm{yr}^{-1}$ (Freiwald et al., 1999). Recently, studies from Stjernsund and Trænadjupet coral-sediment cores (POS-325472 and POS-325-359, respectively) revealed growth rates of $2-6 \mathrm{~mm} \mathrm{a}^{-1}$ (López Correa et al., 2012). The average growth rates measured from the Mingulay Reef 
Complex were more comparable with those from the Norwegian shelf, but were higher and more variable with values as high as $12 \mathrm{~mm} \mathrm{a}^{-1}$ (Figure 5). However, this might be at least partially explained by the greater number of dates taken during the present study from the Mingulay reefs, revealing also high local reef growth rates, compared to the earlier studies. Overall our study at Mingulay confirms the trend for exceedingly rapid Holocene growth rates compared with bathyal coral carbonate mounds examined in the Rockall and Porcupine regions.

\subsection{Holocene L. pertusa occurrence in the NE Atlantic}

During the Holocene, centennial to millennial fluctuations in the influence of the SPG have been documented that affect the North Atlantic inflow and wider North Atlantic climatic conditions (Thornalley et al., 2009; Colin et al., 2010; Copard et al., 2012). These fluctuations had potentially adverse effects on Atlantic Ocean ecosystems (e.g. Stenseth et al., 2003) including L. pertusa. During the Holocene changes in coral reef and mound growth rates have already been attributed to climate driven changes (Frank et al., 2009; López Correa et al., 2012). In this section we compile all the available L. pertusa ages from the NE Atlantic alongside reef and mound growth rates to test whether the relative changes in the North Atlantic inflow to the coral sites could explain variations in L. pertusa occurrence throughout the entire region (Figure 6). We will especially focus our attention on the last $5 \mathrm{ka}$ as the high resolution dating of the coral/sediment cores from the Mingulay Reef Complex may allow short-scale oceanic changes to be identified from changes in growth rates and coral occurrence.

\subsubsection{Present - 2 ka: decline of Lophelia}

From $2 \mathrm{ka}$ to present, lower growth rates were observed across the entire Mingulay Reef Complex. For this period there is a significant decrease in coral occurrence as evidenced by the number of fragments dated in the NE Atlantic (Figure 6). In the Mingulay Reef Complex, we can exclude a bias in sediment core sampling strategy as we obtained 19 additional dates at the surface of the reef. There is a clear gap with no evidence of coral growth between $1.4 \mathrm{ka}$ and the present, despite the fact that live L. pertusa is now reported within the complex (Roberts et al., 2005, 2009). Interestingly, in Norway there is an interruption of reef growth at $1.6 \mathrm{ka}$ recorded 
from coral/sediment cores and very little evidence of coral occurrence from $1.2 \mathrm{ka}$ until recent times, although corals are also growing there today (Mikkelsen et al., 1982; Hovland et al., 1998; Lindberg and Mienert, 2005; López Correa et al., 2012). Very few coral samples from the NE coral carbonate mounds were dated from 0.8 to 2 ka (Frank et al., 2009; Schroder-Ritzrau et al., 2005). The compilation of coral mound growth rates from Rockall Bank and the Porcupine Seabight also show a reduction at $0.9 \mathrm{ka}$ (Frank et al., 2009). However, this is not evident only from considering the age model of core MD 2454G, where a growth rate of $0.2 \mathrm{~mm} \mathrm{a}^{-1}$ was estimated. This may highlight the need to perform a more intensive down-core dating strategy to reveal more short-term climatic events that could have impact coral occurrence and/or to compile growth rate estimates from several locations.

Several climatic anomalies have been described as occurring over the last $2 \mathrm{ka}$ and these tend to group in three major episodes: $0.1-0.7 \mathrm{ka}, 1-1.2 \mathrm{ka}$, and $1.4-1.8$ ka (Mayewski et al., 2004; Thornalley et al, 2009; Wanner et al., 2011; Copard et al., 2012). A drop of $\varepsilon N d$ values recorded from Rockall Bank cold-water corals highlight a stronger influence of SPG water from 1 to $1.25 \mathrm{ka}$ (Copard et al., 2012). Further north, the decreasing near-surface salinity and temperature from 1 to 1.4 ka suggest an enhanced influence of the SPG water to the NAC (Thornalley et al., 2009). Thus, and despite the distinct temporal resolution of the records, they all imply an abrupt enhanced influence of the SPG water relative to the STG water to the coral sites. This oceanic shift could have significantly impacted cold-water coral growth and may thus explain the occurrences of Lophelia within the NE Atlantic (Figure 6). Interestingly, Thornalley et al. (2009) reported evidence that SPG strength declined $1.8 \mathrm{ka}$. Unfortunately, a gap in the SPG records from Rockall Bank does not allow us to easily confirm this interpretation (Figure 6). However, we cannot exclude that this would have contributed to destabilising cold-water coral ecosystems since our results show decreasing coral occurrence and growth within the NE Atlantic from $1.8 \mathrm{ka}$ (Figure 6). We hypothesise that the succession of abrupt oceanic shifts reported over the last $2 \mathrm{ka}$ linked to the increasing influence of SPG circulation significantly destabilised this ecosystem.

\subsubsection{2 ka - 5 ka: Optimum conditions for L. pertusa?}


On Rockall Bank and in the Porcupine Seabight, three major high growth rate $\left(>1 \mathrm{~mm} \mathrm{a}^{-1}\right)$ events are recorded at about 2.5, 3.4 and $5 \mathrm{ka}$. Our records from inshore western Scottish waters also suggest a large occurrence of L. pertusa and relatively high growth rates as early as $4.3 \mathrm{ka}$ lasting until $2.7 \mathrm{ka}$. This period is however punctuated by a few events of lower occurrence/growth rates at $2.7 \mathrm{ka}, 3.2-3.6 \mathrm{ka}$ and to a lesser extent at $3.9 \mathrm{ka}$ and $4.2 \mathrm{ka}$ (Figure 6). The same trend has been observed in Norway, with two major peaks of growth recorded at $3-3.2$ ka and $3.3-$ 3.7 ka (López Correa et al., 2012). These coral records suggest that overall the $2-5$ ka period was particularly favourable for Lophelia growth within the NE Atlantic despite occasionally less intense coral growth across all locations at $2.6-2.8 \mathrm{ka}$ and $3.2-3.6 \mathrm{ka}$.

During the late Holocene, the upper-intermediate waters from around Rockall are characterised by higher $\varepsilon \mathrm{Nd}$ values indicating less influence of the SPG water compared to the rest of the Holocene (Colin et al., 2010). Those conditions appear to have been relatively favourable for cold-water coral reef growth. However, the late Holocene has also been characterised by rapid climate changes (Bond et al., 2001; Mayewski et al., 2004). A small increase in the influence of the SPG was recorded in the North Atlantic at about 3.4 ka (Thornalley et al., 2009; Colin et al., 2010). This event seems to have affected coral growth within the Mingulay Reef Complex as reflected by a decrease in growth rates recorded in between 3.2 and $3.6 \mathrm{ka}$. In Norway, a cooling event was also reported at $3.3 \mathrm{ka}$ in Stjernsundand associated with an overall cooling of the NAC that could also explain the decline in reef growth rate reported in this area (López Correa et al., 2012; Joseph et al., 2012). The rapid climate change occurring $\sim 2.7 \mathrm{ka}$ ago is probably one of the best documented periods of rapid climate change in the late Holocene (Mayewski et al., 2004). This relatively cold event has been associated with a shift in the SPG circulation (Thornalley et al., 2009). Such changes have apparently significantly affected shallower NE Atlantic cold-water coral reefs by reducing their growth and could also partly explain the lack of $\varepsilon \mathrm{Nd}$ record, due to a lower availability of coral samples from Rockall Bank and Porcupine Seabight (Colin et al., 2010; Figure 6). At Mingulay this event is clearly highlighted by an abrupt decrease of coral reef growth rate and no evidence of intense coral growth has been recorded in this area from then until the present day when live reefs are reported. For these shallower coral reef systems (Norway and Mingulay) the 
ocean dynamic did not allow the system to fully recover. However, coral carbonate mounds from the Celtic margin show a faster recovery.

\subsubsection{Early and Mid Holocene L. pertusa occurrence}

No corals older than $4.3 \mathrm{ka}$ were dated from Mingulay, with the exception of one out of sequence coral fragment dated at $7.7 \mathrm{ka}$, which is also the oldest coral fragment known from the complex so far. Despite potential sampling biases for this period, the data reveal L. pertusa occurrence and growth within the NE Atlantic are in agreement with the global hydrological changes over this period (Figure 6). Therefore, the compilation of coral data from the NE Atlantic should enable us to investigate the long-term changes in L. pertusa occurrence and growth from 5 to 11 ka.

Holocene L. pertusa occurrence within the NE Atlantic appears to have started as early as $11.3 \mathrm{ka}$ in Rockall Bank and $10.9 \mathrm{ka}$ in Stjernsund (Norway) (Frank et al., 2009; López Correa et al., 2012). Subsequently, high growth rates were measured at $9.7-10 \mathrm{ka}\left(>3 \mathrm{~mm} \mathrm{a}^{-1}\right)$ in the Porcupine Seabight. Rockall Bank sediment cores show relatively high growth rates $\left(0.6 \mathrm{~mm} \mathrm{yr}^{-1}\right)$ between 8.5 and $9.5 \mathrm{ka}$ (Frank et al., 2009). In Stjernsund, high growth rates $\left(>6 \mathrm{~mm} \mathrm{a}^{-1}\right)$ were similarly recorded from 9.4 to $9.8 \mathrm{ka}$.

The early Holocene (11 to $8 \mathrm{ka}$ ) was characterised by maximal orbital forcing (high summer insolation in the Northern Hemisphere). However, the large North Hemisphere ice sheets and major sea level changes still had a significant influence on climate, water mass organisation and circulation (e.g. Wanner et al., 2008). The growth rate records we discuss from the coral reef frameworks in the early Holocene suggest processes allowing the return of Lophelia pertusa ecosystems in the northern $\mathrm{NE}$ Atlantic $\left(50-70^{\circ} \mathrm{N}\right)$ and relatively favourable environmental conditions for coral settlement and growth (Frank et al., 2009; Frank et al., 2011; López Correa et al., 2012; Henry et al., submitted). This could be explained by the early establishment of near-modern North Atlantic circulation. The weakened SPG influence would have produced hydrological conditions (temperature, productivity, sedimentation processes etc.) suitable for coral occurrence and a northward dispersal of coral larvae from the Mediterranean Sea, where its occurrence persisted during glacial times, through the transport of MOW into the Atlantic (Frank et al., 2004; Thornalley et al., 2009, Colin 
et al., 2010; Frank et al., 2011; Pilet et al., 2011; López Correa et al., 2012; Henry et al., submitted; Figure 6).

Data available from the Norwegian shelf coral/sediment cores show a longterm hiatus from 3.9 - 9.4 ka (López Correa et al., 2012). However, Lophelia samples aging from $6-8 \mathrm{ka}$ were reported within the area (Mikkelsen et al., 1982; Hovland et al., 1998; Lindberg and Mienert, 2005). The available coral/sediment cores from the area did not allowed to report the relative occcurence of Lophelia duing this period, but surface samples dating reveal it presence from 6-8 ka. Rockall Bank and Porcupine Seabight cores present very low growth rates from 6 to 7.6 ka followed by increasing VMGR until 5 ka (Frank et al., 2009).

Cold-water coral based $\varepsilon N d$ records show a strengthened mid-depth SPG influence to Rockall Bank from $5-8$ ka (Colin et al., 2010). In response the Irminger Current was significantly reduced but a constant influence of NAC to the Northern Norwegian water remained (Koç et al., 1993; Colin et al. 2010; Thornalley et al., 2009; Joseph et al., 2012). The stronger influence of SPG water to Rockall Bank may have impacted on the relative occurrence and growth rate of coral mounds from Rockall till the $6 \mathrm{ka}$. Along the Norwegian shelf however, the constant influence of the NAC water would have maintained a suitable environment for coral growth till 6 ka. Although, the number of cold-water coral ages covering this period remains limited, it is possible that the progressive reduction of the SPG may have favoured coral growth along the Celtic margin coral carbonate mounds Frank et al. (2009).

\subsubsection{The last century}

There is no existing inventory of Lophelia pertusa occurrence in the NE Atlantic over the last century, allowing assessing to its relative expansion or decline. However, large live Lophelia pertusa frameworks are presently observed within the NE Atlantic coral site, which indicate that the environmental conditions are conductive for coral growth in this area (Roberts et al., 2009). Rockall Bank $\varepsilon N d$ dataset suggests that the last century is overall dominated by a strong SPG dynamic (Copard et al., 2012; Figure 6). However, significant changes in the SPG dynamic on interannual to interdecadal time scale were also documented over the last 50 years (Hakkinen and Rhines, 2004; Hátún et al., 2005). The last 2 decades for instance were dominated by a weaker SPG dynamic, supporting our hypothesis that environmental 
conditions associated with the SPG dynamic are favorable for coral growth in the NE Atlantic. Thus, as mention per Copard et al. (2012) higher resolution records would be needed to confirm the overall strong SPG dynamic observed from their records over the last century rather than an interannual to interdecadal time scale SPG variability.

Large centennial time scale shifts in SPG dynamic seems to have influenced coral occurrence and reefs/mounds growth during the Holocene. The mechanisms associated with the SPG variability on interannual to interdecadal and its response to the global climate change need to be better constrained to evaluate the potential impact of short time scale SPG dynamic influence on coral growth.

\subsubsection{Summary}

The compilation of the Lophelia pertusa dates from the NE Atlantic coral reefs and mounds reveals periods of synchronous $L$. pertusa occurrence during the Holocene. Estimates of the growth rates provide additional information about the relative increase in coral growth due to stable and/or favourable environmental conditions.

The comparison of our data with centennial SPG circulation changes suggests that corals are very sensitive to changes in water mass properties probably associated with changes in productivity, hydrology, sedimentation processes and larval recruitment. We therefore propose that changes in the relative composition, intensity and direction of the Atlantic inflow during the Holocene on centennial time scale (resulting from changes in the strength and position of the SPG) have significantly influenced the growth, abundance and distribution of L. pertusa in the NE Atlantic.

In the deeper mounds off the Celtic margin, it appears that Lophelia pertusa was almost always present during the Holocene although significant variations in growth rates imply a potential weakening of the corals reef expansion. Our data suggest reefs from shallow inshore environments (such as in Norway and Mingulay) are more sensitive to oceanic changes, and more time is needed for the ecosystem to recover after disruption. This could be partly explained by the local hydrology. The Celtic margin coral sites are also geographically closer to coral larvae dispersed from the Mediterranean following a climatic disruption.

\section{Conclusion}


High-resolution downcore dating of two cold-water coral cores from the Mingulay Reef Complex has allowed us to examine variations in reef growth rates. The average dating resolution was about 100 yrs, allowing very accurate reconstruction of growth rate changes between 1.75 and $4.3 \mathrm{ka}$. Radiocarbon dates were also performed on surface samples from Mingulay reefs to map the age of the complex. By dating both downcore and surface samples we strove to avoid the effect of any patchy coral growth across the reef complex, and our results strongly implicate periods of favourable and unfavourable coral and reef growth.

The growth rates of shallow cold-water coral reefs are significantly higher than those observed for coral carbonate mounds. Growth rates for the Mingulay Reef Complex reach up to $12 \mathrm{~mm} \mathrm{a}^{-1}$ which is the highest growth rate so far found in any cold-water coral reef. Four phases of reduction/interruption of growth in the Mingulay Reef Complex have been found at $1.75-2.8 \mathrm{ka}, 3.2-3.6 \mathrm{ka}$, and to a lesser extent at $3.8-4 \mathrm{ka}$ and $4.2 \mathrm{ka}$. We find no evidence of coral growth from $1.4 \mathrm{ka}$ to present despite more than 50 dates collected within the complex suggesting that environmental conditions during the late Holocene were not conducive for Lophelia pertusa growth, despite its modern occurrence. This seems also to be the case for similar reefs in Norway.

From the compilation of dates from the NE Atlantic cold-water coral reefs and mounds, the period from $2-5 \mathrm{ka}$ was a remarkable period for Lophelia pertusa growth in this region, albeit punctuated by less favourable events. Holocene coral reef growth rates seem to have responded synchronously over a wide region of the NE Atlantic, likely as a result of large-scale shifts in palaeoceanographic regimes. We proposed here that changes in the relative strength and position of the SPG could have significantly impacted not only on the water mass properties but also food supply, sediment processes and larval recruitment within the NE Atlantic coral sites, thus affecting both coral colony and reef growth. Our study further illustrates that the exceptionally high growth rates found in shallow cold-water coral reefs could provide novel records that allow very high-resolution palaeoenvironmental reconstructions of North Atlantic oceanography.

\section{Acknowledgements}


This work was funded through the British Geological Survey (BGS) and the Scottish Alliance for Geoscience, Environment and Society (SAGES). JMR acknowledges support from Heriot-Watt University's Environment \& Climate Changetheme. The authors would like to thank Dr. Nicholas Odling from the University of Edinburgh for XRD screening, Neil Boulton of NIGL for assistance with U-series sample preparation, Callum Murray for sample preparation for ${ }^{14} \mathrm{C}$ analyses and staff at the SUERC AMS Laboratory for the ${ }^{14} \mathrm{C}$ measurement. The authors would also like to thank Matthias López Correa, Norbert Frank and Andrea Schröder-Ritzrau for providing the L. pertusa ages used for this study and Juan Moreno Navas for providing the map presented in figure 2 . We are also very grateful for Christophe Colin, Andre Freiwald and the anonymous reviewer comments and suggestions that have greatly contributed to improve this manuscript. SRN and DL publish with permission of the Executive Director of the British Geological Survey (NERC).

\section{Figures}

\subsection{Figure 1}

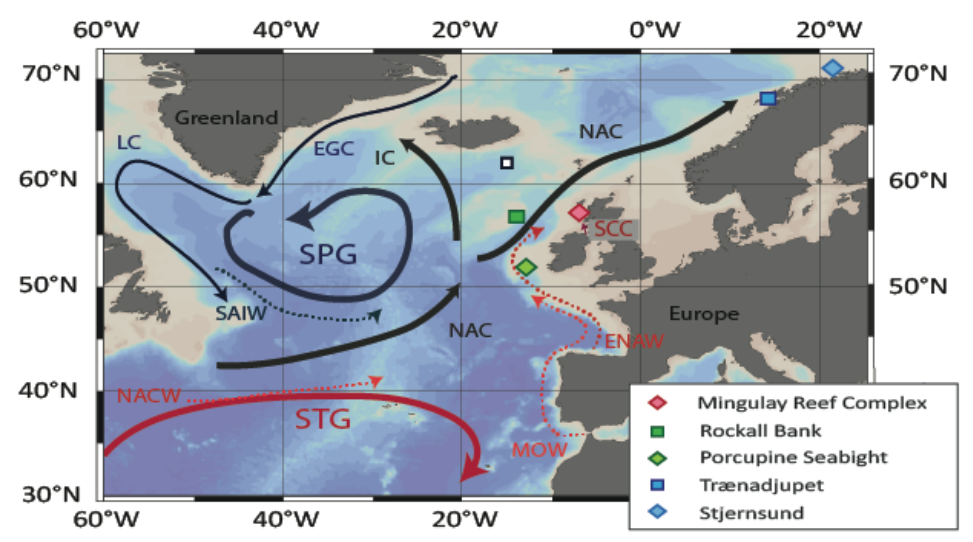

Figure 1: North-East Atlantic coral sites considered in this study relative to a simplified map of the North Atlantic surface currentsand intermediate water masses. Are reported the East Greenland Current (EGC), the Labrador Current (LC), the North Atlantic Current (NAC) and its western branch the Irminger Current (IC), the North Atlantic Central Water (NACW) the Eastern North Atlantic Water (ENAW), the Sub-Arctic Intermediate Water (SAIW), the Mediterranean Outflow Water (MOW), the Scottish Coastal Current (SCC), the Sub-Polar Gyre (SPG) and the SubTropical Gyre (STG). The location of the sediment core RAPiD-12-1K (Thornalley et al., 2009) is symbolised by a black square. 


\subsection{Figure 2}

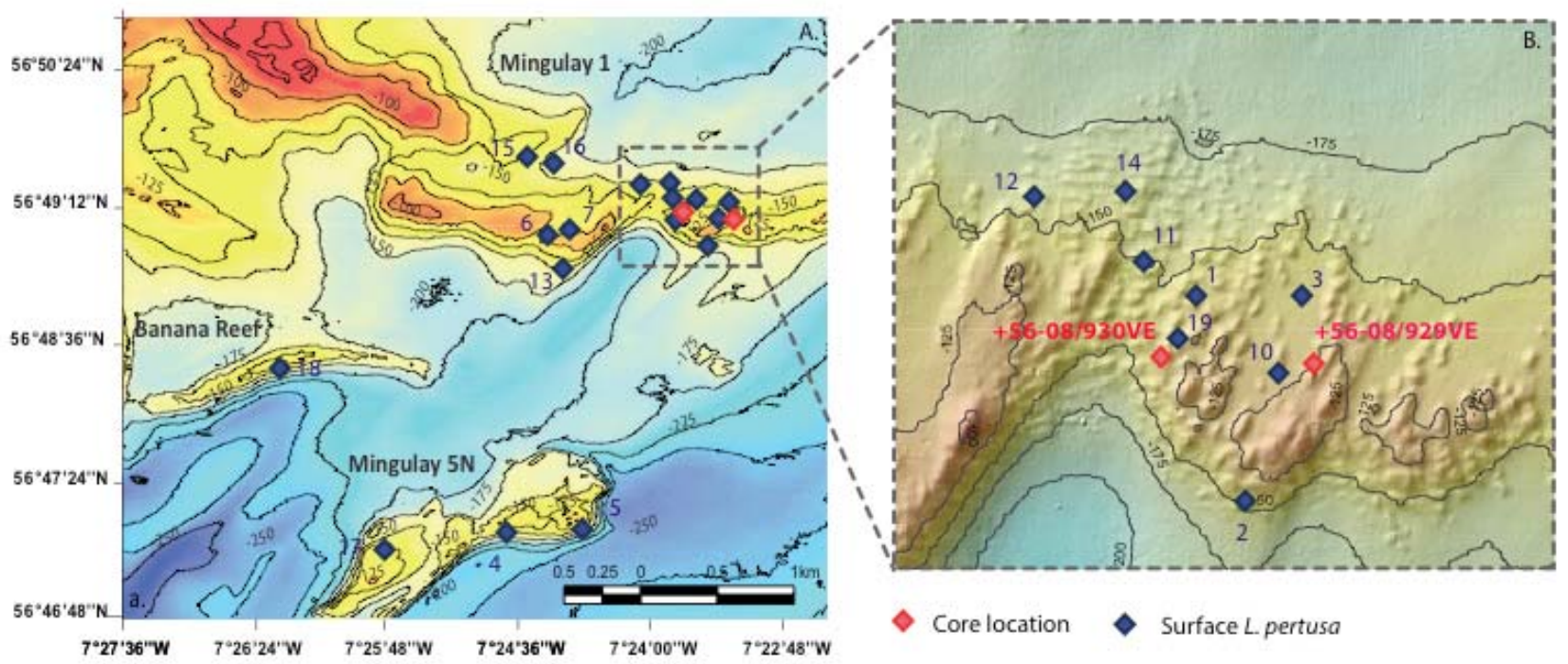

Figure 2: A. Location of the coral/sediment cores (red diamants) and surface L.pertusa samples (blue diamants) sites within Mingulay Reef Complex, B. zoom in the position of the coral/sediment cores. The numbers indicated next to the blue diamantes correspond to the sample information reported in table 3.

\subsection{Figure 3}

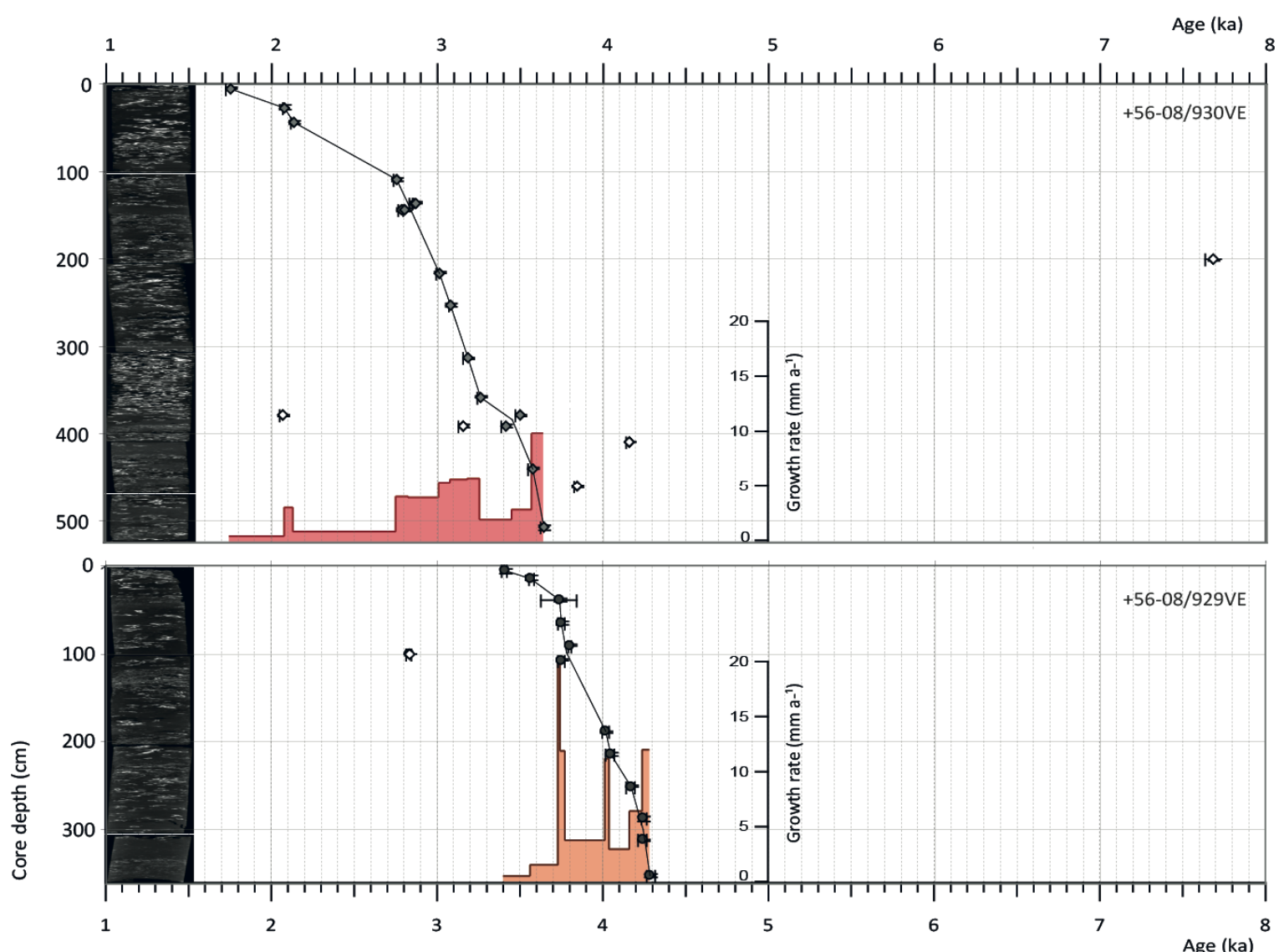

Figure 3: Age (ka)-Depth $(\mathrm{cm})$ relationship of core 930VE and 929VE. On the left of each profile is presented the CT scan image of the cores. All symbols in grey and white are $\mathrm{U}$-series ages.. 


\subsection{Figure 4}

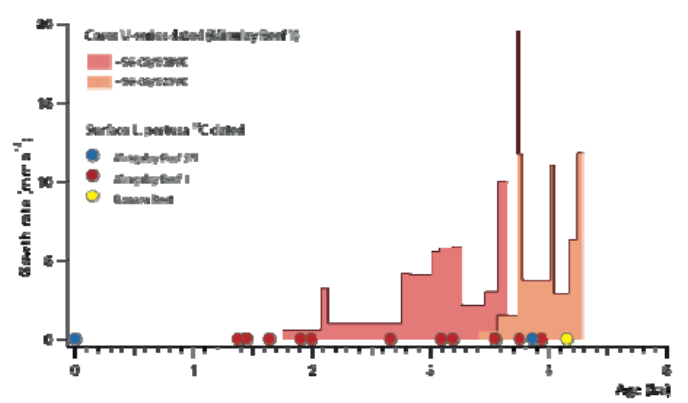

Figure 4: Growth rates estimated from cores 930 (pink) and 929 (orange). The round symbols represent the surface radiocarbon dates obtain from Mingulay 1 (red), Mingulay 5N (blue) and Banana reef (yellow). The blue bands represent the major decrease in growth rate recorded by the two cores.

\subsection{Figure 5}

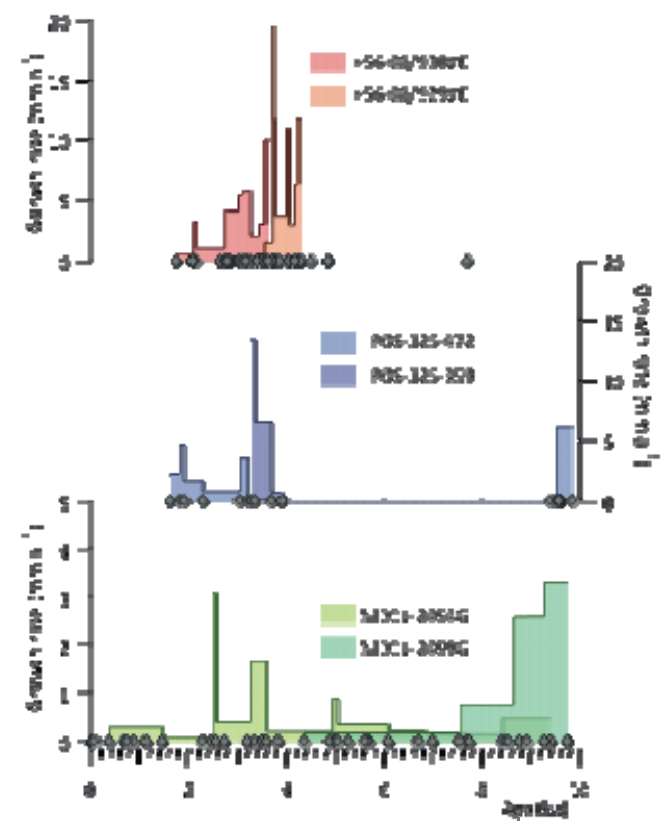

Figure 5: Summary of all the Holocene growth rates $\left(\mathrm{mm} \mathrm{a}^{-1}\right)$ measured so far within the NE Atlantic.

\subsection{Figure 6}




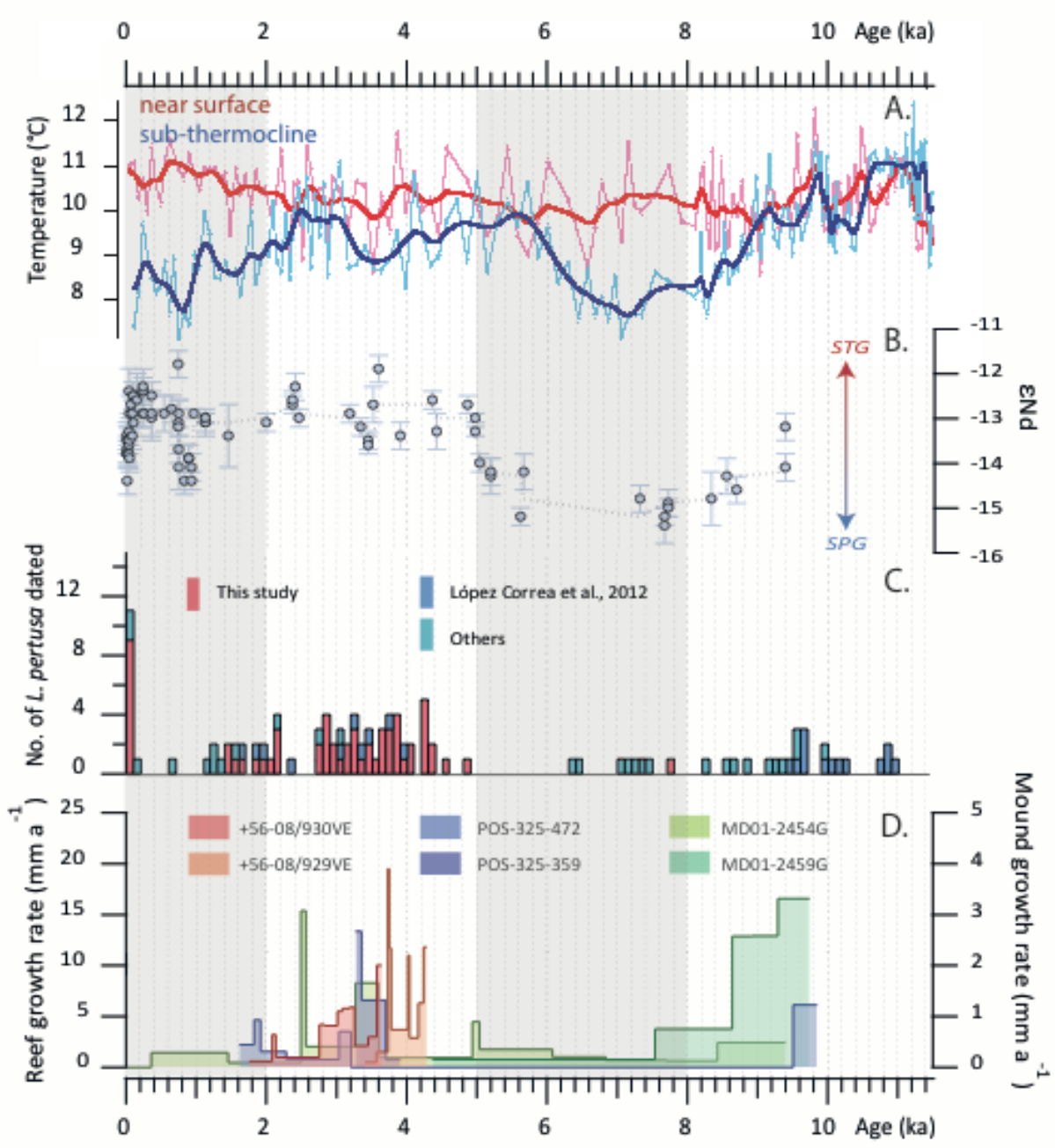

Figure 6: A) Near-surface (red) and sub-thermocline (blue) temperature reconstruction from South Iceland foraminfers (core RAPiD-12-1K; Thornalley et al., 2009), (B) Nd isotopic composition from deep-sea corals from Rockall Bank (core MD01-2454G, 747 m water depth; Colin et al., 2010; Copard et al., 2012), (C) Number of Lophelia pertusa fragments dated from shallow coral reef in Norway and Mingulay (this study, Mikkelsen et al., 1982; Hovland et al., 1998; Lindberg and Mienert, 2005; Schröder-Ritzrau et al., 2005; López Correa et al., 2012), (D) compilation of cold-water coral structure growth rates from Rockall Bank and Porcupine Seabight (green) (Frank et al., 2009), Norway (blue) (López Correa et al., 2012) and Mingulay (red) (This study).

\subsection{Table 1}

\begin{tabular}{|c|c|c|}
\hline & 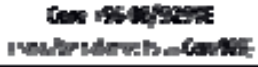 & 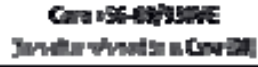 \\
\hline Istivila & 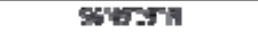 & 9075: \\
\hline Ienginde & 7ขxs & 가날 \\
\hline Eept & Wn & Me \\
\hline Becoment & 3ylm & 5250 \\
\hline
\end{tabular}

Table 1: Mingulay Reef cores information. 


\subsection{Table 2}

\begin{tabular}{|c|c|c|c|c|c|c|c|c|c|c|c|c|c|c|c|}
\hline Sample Name & $\begin{array}{l}\text { NIGL Batch/ } \\
\text { Sample nb }\end{array}$ & Depth $(\mathrm{cm})$ & & in & mp & & 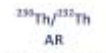 & ${ }^{350} \mathrm{Th} /$ & & & & $\delta^{214} u_{i}\left(\delta_{6}\right)$ & & $\begin{array}{l}\text { Age } \\
(0 a)\end{array}$ & \\
\hline $1929 \mathrm{~d} / 43.9 \mathrm{~cm}$ & $36 / 8$ & $6.0 \pm 3.0$ & 3.356 & 10.05 & 0.1409 & \pm 0.21 & $2562.6 \pm 0.4$ & 0.03533 & $=0.50$ & 1.1455 & \pm 0.21 & $146.9 \pm 2.4$ & 3.405 & $=$ & 0.019 \\
\hline $2929 \mathrm{~N} / 412-17 \mathrm{~cm}$ & $24 / 1$ & $145 \pm 25$ & 3.748 & \pm 0.08 & 0.1361 & \pm 0.29 & $3108.8 \pm 0.4$ & 0.03708 & $\approx 0.38$ & 1.1485 & \pm 0.30 & $1500 \pm 3.5$ & 3.567 & \pm & 0.018 \\
\hline $3929 \mathrm{~N} / 43 \mathrm{~s} \cdot 41 \mathrm{~cm}$ & $38 / 1$ & $395 \pm 1.5$ & 3.087 & \pm 0.05 & 0.1505 & 10.30 & $2419.1 \pm 27$ & 0.03871 & $=2.74$ & 1.1460 & \pm 0.21 & $147.6 \pm 2.4$ & 3.734 & \pm & 0.104 \\
\hline $4929 \mathrm{~N} / 464.67 \mathrm{~cm}$ & $38 / 2$ & $65.5 \pm 1.5$ & 3.178 & \pm 0.05 & 0.1796 & \pm 0.18 & $2098.1 \pm 0.2$ & 0.03888 & $=0.39$ & 1.1471 & \pm 0.21 & $148.7 \pm 2.4$ & 3.747 & $=$ & 0.017 \\
\hline $5929 \mathrm{~N} / 400-91 \mathrm{~cm}$ & $39 / 9$ & $905 \pm 0.5$ & 3.049 & \pm 0.05 & 0.1250 & \pm 0.07 & $2925.7 \pm 0.2$ & 0.03939 & \pm 0.33 & 1.1462 & \pm 0.20 & $147.8 \pm 2.4$ & 3.800 & \pm & 0.015 \\
\hline $6929 \mathrm{~N} / 4100-101 \mathrm{~cm}$ & $38 / 3$ & $1005=0.5$ & 3.984 & \pm 0.06 & 0.1771 & \pm 0.07 & $2020.8 \pm 0.2$ & 0.02945 & $=0.40$ & 1.1468 & \pm 0.21 & $147.9 \pm 2.4$ & 2.828 & \pm & 0.013 \\
\hline $7929 \mathrm{~B} / 4106.10 \mathrm{~cm}$ & $36 / 9$ & $107.0=1.0$ & 3.099 & \pm 0.05 & 0.1458 & \pm 0.21 & $2516.2 \pm 0.4$ & 0.03885 & $=0.50$ & 1.1452 & \pm 0.20 & $146.7 \pm 2.4$ & 3.751 & \pm & 0.021 \\
\hline $8929 \mathrm{~B} / 4188.189 \mathrm{~cm}$ & $35 / 3$ & $1885 \neq 0.5$ & 3.124 & \pm 0.05 & 0.2477 & \pm 0.11 & $1598.3 \neq 0.1$ & 0.04150 & $=0.45$ & 1.1429 & \pm 0.21 & $144.5 \pm 2.4$ & 4.019 & \pm & 0.020 \\
\hline $9929 \mathrm{C} / 4213-216 \mathrm{~cm}$ & $38 / 6$ & $2145 \div 1.5$ & 2.765 & \pm 0.06 & 0.2596 & \pm 0.07 & $1361,3 \pm 0.2$ & 0.04182 & \pm 0.52 & 1.1453 & \pm 0.21 & $1470 \pm 2.4$ & 4.043 & \pm & 0.023 \\
\hline $10929 \mathrm{c} / 4249-252 \mathrm{~cm}$ & $38 \% 7$ & $2505: 1.5$ & 3.090 & \pm 0.05 & 0.2793 & \pm 0.07 & $1456.9 \pm 0.2$ & 0.06309 & \pm 0.50 & 1.1455 & \pm 0.21 & $147.2 \pm 2.4$ & 4166 & \pm & 0.023 \\
\hline $11929 \mathrm{cl} 4284.290 \mathrm{~cm}$ & $35 / 1$ & $287.0 \pm 3.0$ & 2.725 & \pm 0.05 & 0.1465 & \pm 0.11 & $2487.6 \div 0.2$ & 0.04391 & $=0.35$ & 1.1455 & \pm 0.21 & $1472 \pm 2.4$ & 4.248 & $=$ & 0.018 \\
\hline $12929 \mathrm{D} / 4310-312 \mathrm{~cm}$ & $36 / 10$ & $3110 \div 10$ & 3.07 & \pm 0.05 & 0.2044 & \pm 021 & $2010.2 \pm 0.4$ & 0.06378 & \pm 0.53 & 1.1446 & \pm 0.20 & $146.3 \pm 2,4$ & 4.238 & \pm & 0.025 \\
\hline $13929 \mathrm{D} / 4349.353 \mathrm{~cm}$ & $35 / 6$ & $351.0 \pm 2.0$ & 2.981 & \pm 0.05 & 0.3327 & $=0.11$ & $1213.6 \neq 0.1$ & 0.04427 & $=0.56$ & 1.1445 & \pm 0.21 & $146.3 \pm 2.4$ & 4.287 & $=$ & 0.026 \\
\hline $14930 \mathrm{~N} / 646 \mathrm{~cm}$ & $35 / 8$ & $5.0 \pm 1.0$ & 3.474 & \pm 0.05 & 0.4740 & \pm 0.13 & $415.8 \pm 0.2$ & 0.01825 & \pm 1.53 & 1.1427 & \pm 0.20 & $143.4 \pm 2,3$ & 1.750 & $t$ & 0.027 \\
\hline 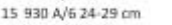 & $35 / 7$ & $26.5 \pm 2.5$ & 3.066 & \pm 0.06 & 0.1159 & \pm 0.11 & $1752.2 \neq 0.2$ & 0.02171 & $=0.42$ & 1.1450 & \pm 0.21 & $145.8 \pm 2.4$ & 2.081 & $=$ & 0.010 \\
\hline $16930 \mathrm{~N} / 642-45 \mathrm{~cm}$ & $39 / 1$ & $43.5 \div 1.5$ & 2.996 & \pm 0.07 & 0.2519 & \pm 0.07 & $814.2 \pm 0.2$ & 0.02229 & \pm 0.81 & 1.1465 & \pm 0.23 & $147.4 \pm 2.7$ & 2.134 & \pm & 0.018 \\
\hline $17930 \mathrm{~g} / 6107.110 \mathrm{~cm}$ & $39 / 3$ & $1085 \neq 1.5$ & 3.230 & \pm 0.08 & 0.3177 & A 0.07 & $894.9 \pm 0.2$ & 0.02868 & $=0.74$ & 1.1462 & \pm 0.22 & $147.4 \pm 2.5$ & 2.754 & \pm & 0.022 \\
\hline $18930 \mathrm{~g} / 6124.127 \mathrm{~cm}$ & $35 / 9$ & $1355=1.5$ & 3.018 & \pm 0.05 & 0.3137 & 10.13 & $875.1 \pm 0.2$ & 0.02963 & $=0.75$ & 1.1418 & \pm 0.21 & $142.9 \pm 2.4$ & 2.858 & \pm & 0.023 \\
\hline $19930 \mathrm{~B} / 6134.137 \mathrm{~cm}$ & $39 / 10$ & $1355: 1.5$ & 3.020 & \pm 0.05 & 0.2414 & \pm 0.26 & $1144.5 \pm 0.4$ & 0.02989 & \pm 0.66 & 1.1464 & \pm 0.21 & $147.6 \pm 2.4$ & 2.871 & \pm & 0.020 \\
\hline $20930 \mathrm{~g} / 6142 \cdot 146 \mathrm{~cm}$ & $36 / 1$ & $144.0 \pm 20$ & 2.806 & \pm 0.05 & 0.1327 & 10.07 & $1866.4 \pm 0.1$ & 0.02894 & $=0.41$ & 1.1455 & \pm 0.20 & $146.6 \pm 2.4$ & 2.782 & \pm & 0.013 \\
\hline $21930 \mathrm{~B} / 6142.146 \mathrm{~cm}$ & $40 / 2$ & $144.0 \pm 2.0$ & 2.824 & \pm 0.05 & 0.1503 & \pm 0.21 & $1674.8 \geq 0.4$ & 0.02920 & $=0.56$ & 1.1456 & \pm 0.21 & $146.7 \pm 2.4$ & 2.807 & $\approx$ & 0.017 \\
\hline $22930 \mathrm{~B} / 6199-202 \mathrm{~cm}$ & $39 / 4$ & $2005=1.5$ & 2.770 & \pm 0.10 & 0,4841 & \pm 0.07 & $1364.2 \pm 0.2$ & 0.07800 & \pm 0.52 & 1.1431 & \pm 0.25 & $1463 \pm 3.0$ & 7.675 & \pm & 0.046 \\
\hline $23930 \mathrm{c} / 6214.217 \mathrm{~cm}$ & $39 / 5$ & $2155=1.5$ & 3.568 & \pm 0.05 & 0.2422 & \pm 0.07 & $1410.4 \pm 0.2$ & 0.03133 & $=0.51$ & 1.1460 & 0.21 & $147.3 \pm 2.4$ & 3.012 & $\approx$ & 0.017 \\
\hline $24930 \mathrm{c} / 6251.254 \mathrm{~cm}$ & $38 / 9$ & $2525=1.5$ & 3.025 & \pm 0.07 & 0.0999 & 10.20 & $2949.4 \neq 0.3$ & 0.03199 & $=0.35$ & 1.1448 & \pm 0.21 & $1451 \pm 2.4$ & 3.080 & \pm & 0.013 \\
\hline $25930 \mathrm{o} / 6312.31 \mathrm{~cm}$ & $36 / 2$ & $3130=1.0$ & 2.747 & \pm 0.05 & 0.3625 & \pm 0.06 & $769.4 \pm 01$ & 0.03303 & \pm 0.84 & 1.1437 & \pm 0.20 & $145.0 \pm 2.4$ & 3.185 & \pm & 0.028 \\
\hline $26930 \mathrm{D} / 6356-358 \mathrm{~cm}$ & $39 / 7$ & $3570 \div 10$ & 3.038 & \pm 0.05 & 0.2515 & \pm 0.07 & $1251.5 \pm 0.2$ & 003387 & $=0.55$ & 1.1465 & \pm 0.21 & $147.8 \pm 2,4$ & 3.259 & \pm & 0.020 \\
\hline $27930 \mathrm{D} / 6377.379 \mathrm{~cm}$ & $36 / 3$ & $3780=1.0$ & 2.305 & \pm 0.05 & 0.3012 & \pm 0.07 & $851.8 \neq 0.1$ & 0.03625 & $=0.76$ & 1.1450 & \pm 0.20 & $146.4 \pm 2.4$ & 3.997 & $=$ & 0.028 \\
\hline $289300 / 6377-379 \mathrm{~cm}$ & $\begin{array}{l}30 / 3 \\
40 / 3\end{array}$ & $3780=1.0$ & 3.803 & $\begin{array}{l} \pm 0.05 \\
\pm 0\end{array}$ & 0.2619 & \pm 0.12 & $961.0 \pm 0.4$ & 0.02159 & \pm 0.76 & 1.1447 & \pm 0.21 & $1455 \pm 2.4$ & 2070 & $t$ & 0.016 \\
\hline $29930 \mathrm{D} / 6386-392 \mathrm{~cm}$ & $24 / 8$ & $3900 \div 20$ & 2.762 & \pm 0.05 & 0.2425 & \pm 0.09 & $1232.1 \pm 0.2$ & 0.03535 & \pm 0.56 & 1.1449 & \pm 0.21 & $146.4 \pm 2.5$ & 3.409 & \pm & 0.021 \\
\hline $30930 \mathrm{D} / 6388.392 \mathrm{~cm}$ & $40 / 4$ & $3900 \div 2.0$ & 3.234 & \pm 0.05 & 0.3715 & \pm 0.09 & $875.8 \pm 0.4$ & 0.03278 & $=0.81$ & 1.1447 & \pm 0.21 & $146 a \pm 2.4$ & 3.158 & $=$ & 0.027 \\
\hline $31930 \mathrm{D} / 640 \mathrm{6}-409 \mathrm{~cm}$ & $36 / 5$ & $4085=0.5$ & 2.429 & \pm 0.05 & 0.2659 & \pm 0.06 & $1203.9 \pm 0.1$ & 0.04307 & \pm 0.56 & 1.1465 & \pm 0.21 & $148.2 \pm 2.4$ & 4.161 & \pm & 0.025 \\
\hline $32930 \mathrm{E} / 6438-460 \mathrm{~cm}$ & $36 / 6$ & $4390=1.0$ & 2.781 & \pm 0.05 & 0.2672 & \pm 0.06 & $1175.8 \pm 01$ & 003691 & $\begin{array}{l}0.57 \\
\end{array}$ & 1.1415 & \pm 0.20 & $1429 \pm 2.4$ & 3.573 & 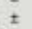 & 0.022 \\
\hline $33930 \mathrm{E} / 6.459 .461 \mathrm{~cm}$ & $40 / 5$ & $4600=10$ & 2.615 & \pm 0.05 & 0.2042 & \pm 0.10 & $1556.7=0.4$ & 0.03981 & $=0.56$ & 1.1447 & \pm 0.21 & $146.3 \pm 2.4$ & 3.847 & $\therefore$ & 0.024 \\
\hline $34930 \mathrm{~F} / 6505.510 \mathrm{~cm}$ & $39 / 8$ & $5075 \div 25$ & 2.871 & \pm 0.05 & 0.2703 & \pm 0.07 & $1227.6 \pm 0.2$ & 0.03779 & \pm 0.57 & 1.1468 & \pm 0.21 & $148.3 \pm 2.4$ & 3.641 & $t$ & 0.022 \\
\hline 35 Grab 1555.10 & 35 & se & 2.3 & \pm 0.05 & & \pm 0 & $20.2 \pm$ & & $=5$ & 1.1. & \pm 0.21 & $1448 \pm 2.4$ & 0.022 & \pm & 0.013 \\
\hline 36 Grob 1555.10 & $40 / 6$ & seafloot & 2.527 & \pm 0.05 & 0.0678 & \pm 0.28 & $35.4 \pm 15$ & 0.0002243 & \pm 24.14 & 1.1485 & \pm 0.23 & $1485 \pm 2.6$ & 0.021 & \pm & 0.005 \\
\hline
\end{tabular}

Table 2: U-series dates from downcore Lophelia pertusa samples. The depth represents the location of the coral fragments within the cores $+/-$ half of its length.

\subsection{Table 3}

Table 3: Radiocarbon age of Lophelia pertusa samples from Mingulay Reef Complex seabed. Post bomb samples are highlighted in blue and italic. Data presented in the table were calibrated using the program Oxcal 4.1 (Bronk Ramsey, 2009)and the dataset (MARINE 09) (Reimer et al., 2009), the ages were also corrected from local $\Delta R=79 \pm 17$ (Ascough et al., 2004).

\begin{tabular}{|c|c|c|c|c|c|c|c|c|c|c|c|c|}
\hline & Sample Number & Sample Name & $\begin{array}{l}\text { Sample } \\
\text { Collector }\end{array}$ & $\begin{array}{l}\text { Collection } \\
\text { Date }\end{array}$ & Location & $\begin{array}{l}\text { Latitude } \\
\text { oN/s }\end{array}$ & $\begin{array}{l}\text { Longitude } \\
\mathrm{OE} / \mathrm{W}\end{array}$ & Depth $(m)$ & $\begin{array}{c}\delta^{13} c^{p 0 B} \pm 0.1 \\
(\%(\%)\end{array}$ & $\begin{array}{c}\text { Conventional }{ }^{14} \mathrm{C} \text {-age } \\
\text { (ka BP) }\end{array}$ & \multicolumn{2}{|c|}{$\begin{array}{c}\text { Calibrated age-range } \pm 2 \sigma \\
\text { (cal ka BP) }\end{array}$} \\
\hline & SUERC-33518 & $2010-0223 / 002$ & Video-grab & $23 / 02 / 10$ & Mingulay 1 & $56^{\prime} 49^{\prime} 24^{\prime \prime}$ & $7^{\prime} 23^{\prime} 42^{\prime \prime}$ & 125 & -8.8 & \multicolumn{3}{|c|}{ Past bomb } \\
\hline 2 & SUERC-33519 & 1151 & Video-grab & $15 / 05 / 05$ & Mingulay 1 & $56^{6} 4^{\prime} 0^{\prime \prime \prime}$ & $7^{*} 23^{\prime} 36^{\prime \prime}$ & 121 & -5.1 & $1.821=0.035$ & 1341 & 1540 \\
\hline 3 & SUERC-33522 & 1154 & Video-orab & $15 / 05 / 05$ & Mingulay 1 & $56^{\circ} 49^{\prime} 24^{\prime \prime}$ & $7^{2} 23^{\prime} 28^{\prime \prime}$ & 146 & -6. & \multirow{2}{*}{\multicolumn{3}{|c|}{$\begin{array}{l}\text { Post bomb } \\
\text { Post bomb }\end{array}$}} \\
\hline 4 & SUERC-33523 & 1156 & eo-grab & $15 / 05 / 05$ & Mingulay $5 \mathrm{~N}$ & $56^{\circ} 47^{\prime} 14^{\prime \prime}$ & $7^{2} 24^{\prime} 59^{\prime \prime}$ & 140 & -7 & & & \\
\hline & SUERC-33524 & 1157 & Video-grab & $15 / 05 / 05$ & Mingulay SN & $56^{\circ} 47^{\prime} 15^{\prime \prime}$ & $7^{\prime} 24^{\prime} 27^{\prime \prime}$ & 122 & -6.7 & $0.404 \pm 0$. & post1950 & 116 \\
\hline 6 & SUERC-33525 & 1168 & Grab gravo & $\begin{array}{l}18 / 05 / 05 \\
18\end{array}$ & Mingulay 1 & $\begin{array}{l}56^{\circ} 49^{\prime} 11^{\prime \prime} \\
\end{array}$ & $7^{\prime 2} 24^{4} 43^{\prime \prime}$ & 125 & -5.3 & $3.853 \pm 0.035$ & 3813 & $\begin{array}{l}116 \\
4057\end{array}$ \\
\hline 7 & SUERC- 33526 & 1169 & Grab & $18 / 05 / 05$ & Mingulay 1 & $56^{\circ} 49^{\prime} 14^{\prime \prime}$ & $77^{\prime} 24^{\prime 3} 4^{\prime \prime}$ & 128 & -4.3 & $3.247 \pm 0.035$ & 3058 & 3313 \\
\hline 8 & SUERC-33527 & 929 VE $3.9 \mathrm{~cm}$ & Vibro-core & $04 / 10 / 07$ & Mingulay 1 & $56^{6} 44^{\prime} 19^{\prime \prime}$ & $7^{\circ} 23^{\prime} 27^{\prime \prime}$ & 12 & $-5.2-3>1$ & $3.728 \pm 0.035$ & 3633 & 3865 \\
\hline & SUERC- 33528 & 930 VE $4-6 \mathrm{~cm}$ & Vibro-core & $04 / 10 / 07$ & Mingulay 1 & $56^{\circ} 49^{\prime} 20^{\prime \prime}$ & $7^{\prime 2} 23^{\prime} 47^{\prime \prime}$ & & -5.4 & $2.283 \pm 0.037$ & 1877 & 2104 \\
\hline 10 & SUERC-33529 & $56-08 / 9270-2 \mathrm{~cm}$ & Vibro-core & $24 / 09 / 07$ & Mingulay 1 & $56^{\circ} 49^{\prime} 18^{\prime \prime}$ & $77^{\prime} 23^{\prime} 31^{\prime \prime}$ & 123.5 & -6.8 & $3.184 \pm 0.037$ & 2956 & 3227 \\
\hline & SUERC-36967 & HWU20110608/009A & Video-grab & $08 / 06 / 11$ & Mingulay 1 & $56^{\circ} 49^{\prime} 27^{\prime \prime}$ & $7^{\prime 2} 23^{\prime} 49^{\prime \prime}$ & 162 & -6.3 & $0.484 \pm 0.037$ & 229 & 0 \\
\hline & SUERC-36968 & HWU20110608/012A & Video-grab & $08 / 06 / 11$ & Mingulay 1 & $56^{\circ} 49^{\prime} 33^{\prime \prime}$ & $7 " 23^{\prime} 52^{\prime \prime}$ & 162 & -6.9 & $1.989 \pm 0.035$ & 1755 & 1528 \\
\hline 13 & SUERC-36969 & HWU20110609/002A & Video-grab & $09 / 06 / 11$ & Mingulay 1 & $56^{\circ} 48^{\prime} 59^{\prime \prime}$ & $7^{\prime 2} 23^{\prime} 36^{\prime \prime}$ & 162 & -5.3 & $1.827 \pm 0.035$ & 1547 & 1345 \\
\hline 14 & SUERC-36972 & HWU20110707/004A & Video-grab & $07 / 07 / 11$ & Mingulay 1 & $56^{\circ} 49^{\prime} 32^{\prime \prime}$ & $7^{\prime 2} 23^{\prime} 0 a^{\prime \prime}$ & 135 & -6.6 & \multicolumn{3}{|c|}{ Post bomb } \\
\hline 15 & SUERC-36973 & HWU20110707/008A & Video-erab & $07 / 07 / 11$ & Mingulay 1 & $56^{\circ} 494^{4} 2^{\prime \prime}$ & $7^{\prime \prime 2} 23^{\prime} 50^{\prime \prime}$ & 134 & -59 & $2211 \div 0.035$ & 2012 & 1798 \\
\hline & SUERC-36974 & HWU201107 & & & & 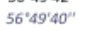 & & 154 & . & \multicolumn{3}{|c|}{ t tomb } \\
\hline 17 & SUERC-36975 & $56-08 / 928$ & vibro-corer & $26 / 09 / 07$ & Mingulay $5 \mathrm{~N}$ & $56^{\circ} 47^{\prime} 08^{\prime \prime}$ & $7^{\prime} 25^{\prime} 48^{\prime \prime}$ & 136 & -5.1 & & 2773 & 2548 \\
\hline 18 & SUERC-36976 & D340B/1488 & rab & $01 / 07 / 09$ & Banana & $56^{\circ} 48^{\prime} 19^{\prime \prime}$ & $7^{\prime 2} 26^{\prime} 31^{\prime \prime}$ & 118 & -4.8 & $4.026=$ & 4293 & 4006 \\
\hline & & & & & & & & & & & & \\
\hline
\end{tabular}




\section{References}

Andersen, M.B., Stirling, C.H., Potter, E.-K., Halliday, A.N., Blake, S.G., McCulloch, M.T., Ayling, B.F., O'Leary, M., 2008. High-precision U-series measurements of more than 500,000 year old fossil corals. Earth and Planetary Science Letters 265, 229-245.

Ascough, P.L., Cook, G.T., Dugmore, A.J., Barber, J., Higney, E., Scott, E.M., 2004. Holocene variations in the Scottish marine radiocarbon reservoir effect. Radiocarbon 46, 611-620.

Barber, D.C., Dyke, A., Hillaire-Marcel, C., Jennings, A.E., Andrews, J.T., Kerwin, M.W., Bilodeau, G., McNeely, R., Southon, J., Morehead, M.D., Gagnon, J.M., 1999. Forcing of the cold event of 8,200 years ago by catastrophic drainage of Laurentide lakes. Nature 400, 344-348.

Bond, G., Kromer, B., Beer, J., Muscheler, R., Evans, M.N., Showers, W., Hoffmann, S., Lotti-Bond, R., Hajdas, I., Bonani, G., 2001. Persistent Solar Influence on North Atlantic Climate During the Holocene. Science 294, 2130-2136.

Bronk Ramsey, C., 2009. Bayesian analysis of radiocarbon dates. Radiocarbon 51, 337-360.

Came, R.E., Oppo, D.W., McManus, J.F., 2007. Amplitude and timing of temperature and salinity variability in the subpolar North Atlantic over the past 10 k.y. Geology $35,315-318$.

Cheng, H., Edwards, R.L., Hoff, J., Gallup, C.D., Richards, D.A., Asmerom, Y., 2000. The half-lives of uranium-234 and thorium-230. Chemical Geology 169, 17-33.

Colin, C., Frank, N., Copard, K., Douville, E., 2010. Neodymium isotopic composition of deep-sea corals from the NE Atlantic: implications for past hydrological changes during the Holocene. Quat. Sci. Rev. 29, 2509-2517.

Copard, K., Colin, C., Douville, E., Freiwald, A., Gudmundsson, G., De Mol, B., Frank, N., 2010. Nd isotopes in deep-sea corals in the North-eastern Atlantic. Quat. Sci. Rev. 29, 2499-2508.

Copard, K., Colin, C., Henderson, G.M., Scholten, J., Douville, E., Sicre, M.A., Frank, N., 2012. Late Holocene intermediate water variability in the northeastern Atlantic as recorded by deep-sea corals. Earth and Planetary Science Letters 313-314, 34-44.

Craig, R.E., 1959. Hydrography of Scottish coastal waters. Marine Research 1958 2, 33.

Davies, A.J., Duineveld, G.C.A., Lavaleye, M.S.S., Bergman, M.J.N., Van Haren, H., Roberts, J.M., 2009. Downwelling and deep-water bottom currents as food supply mechanisms to the cold-water coral Lophelia pertusa (Scleractinia) at the Mingulay Reef complex. Limnology and Oceanography 54(2), 620-629.

Davies, A.J., Wisshak, M., Orr, J.C., Murray Roberts, J., 2008. Predicting suitable habitat for the cold-water coral Lophelia pertusa (Scleractinia). Deep Sea Research Part I: Oceanographic Research Papers 55, 1048-1062. 
De Mol, B., Rensbergen, P.V., Pillen, S., Van Herreweghe, K., Van Rooij, D., McDonnell, A., Huvenne, V.A.I., Ivanov, M., Swennen, R., Henriet, J.-P., 2002. Large deep-water coral banks in the Porcupine Basin, southwest of Ireland. Marine Geology 188, 193-231.

Delanghe, D., Bard, E., Hamelin, B., 2002. New TIMS constraints on the uranium238 and uranium-234 in seawaters from the main ocean basins and the Mediterranean Sea. Marine Chemistry 80, 79-93.

Dodds, L.A., Roberts, J.M., A.C., T., Marubini, F., 2007. Metabolic tolerance of the cold-water coral Lophelia pertusa (Scleractinia) to temperature and dissolved oxygen change. Journal of Experimental Marine Biology and Ecology 349, 205-214.

Dorschel, B., 2003. Late Quaternary Development of a deep-water Carbonate Mound in the northeast Atlantic, am Fachbereich Geowissenschaften. der Universitat Bremen, Bremen, p. 87.

Dorschel, B., Hebbeln, D., Rüggeberg, A., Dullo, C., 2007. Carbonate budget of a cold-water coral carbonate mound: Propeller Mound, Porcupine Seabight. Int J Earth Sci 73-83.

Douarin, M., Sinclair, D., Elliot, M., Henry, L.-A., Long, D., Mitchison, F., Roberts, J.M., (in review) Fossil biodiversity at the Mingulay Reef Complex: a model of coral reef build-up. Deep-Sea Research II.

Douville, E., Sallé, E., Frank. N, Eisele, M., Pons-Branchu, E., Ayrault, S., 2010. Rapid and Accurate U-Th Dating of Ancient Carbonates using Inductively Coupled Plasma-Quadrupole Mass Spectrometry. Chemical Geology 272, 1-11.

Edwards, R.L., Chen, J.H., Wasserburg, G.J., 1988. ${ }^{238} \mathrm{U}_{-}{ }^{234} \mathrm{U}_{-}{ }^{230} \mathrm{Th}^{2}{ }^{232} \mathrm{Th}$ systematics and the precise measurement of time over the past 500,000 years. Earth and Planetary Science Letters 81, 175-192.

Eisele, M., Frank, N., Wienberg, C., Hebbeln, D., Lopez Correa, M., Douville, E., Freiwald, A., 2011. Productivity controlled cold-water coral growth periods during the last glacial off Mauritania. Marine Geology 280, 143-149.

Eisele, M., Hebbeln, D., Wienberg, C., 2008. Growth history of a cold-water coral covered carbonate mound - Galway Mound, Porcupine Seabight, NE-Atlantic. Marine Geology 253, 160-169.

Frank, N., Freiwald, A., Lopez Correa, M., Wienberg, C., Eisele, M., Hebbeln, D., Van Rooij, D., Henriet, J.-P., Colin, C., van Weering, T., de Haas, H., BuhlMortensen, P., Roberts, J.M., De Mol, B., Douville, E., Blamart, D., Hatte, C., 2011. Northeastern Atlantic cold-water coral reefs and climate. Geology 39, 743-746.

Frank, N., Lutringer, A., Paterne, M., Blamart, D., Henriet, J.-P., van Rooij, D., van Weering, T., 2005. Deep-water corals of the notheastern Atlantic margin: carbonate mound evolution and upper intermediate ventilation during the Holocene. Cold-water Corals and Ecosystems, Springer-Verlag Berlin Heidelberg, 113-133.

Frank, N., Paterne, M., Ayliffe, L., van Weering, T., Henriet, J.-P., Blamart, D., 2004. Eastern North Atlantic deep-sea corals: tracing upper intermediate water $\Delta^{14} \mathrm{C}$ during the Holocene. Earth and Planetary Science Letters 219, 297-309.

Frank, N., Ricard, E., Lutringer-Paquet, A., Van der Land, C., Colin, C., Blamart, D., Foubert, A., Van Rooij, D., Henriet, J.-P., de Haas, H., Van Weering, T.C.E., 2009. 
The Holocene occurrence of cold water corals in the NE Atlantic: Implications for coral carbonate mound evolution. Marine Geology 266, 129-142.

Frederiksen, R., Jensen, A., Westerberg, H.k., 1992. The distribution of the scleractinian coral Lophelia pertusa around the Faroe islands and the relation to internal tidal mixing. SARSIA 77, 157-171.

Freiwald, A., Wilson, J.B., Henrich, R., 1999. Grounding Pleistocene icebergs shape recent deep-water coral reefs. Sedimentary Geology 125, 1-8.

Genin, A., Dayton, P.K., Lonsdale, P.F., Spiess, F.N., 1986. Corals on seamount peaks provide evidence of current acceleration over deep-sea topography. Nature 322.

Häkkinen, S., and Rhines, P.B., 2004. Decline of Subpolar North Atlantic Circulation During the 1990s. Science, 304(5670), 555-559.

Hátún, H., Sandø, A.B., Drange, H., Hansen, B., Valdimarsson, H., 2005. Influence of the Atlantic Subpolar Gyre on the Thermohaline Circulation. Science 309, 1841-1844.

Hiess, J., Condon, D.J., McLean, N, Noble, S.R., 2012. ${ }^{238} \mathrm{U} /{ }^{235} \mathrm{U}$ systematics in terrestrial uranium-bearing minerals. Science 335, 1610-1614.

Henriet, J.-P., De Mol, B., Vanneste, M., Huvenne, V.A.I., Van Rooij, D., 2001. Carbonate mounds and slope failures in the Porcupine Basin: a development model involving fluid venting. Geological Society, London, Special Publications 188, 375383.

Henry, L.-A., Frank, N., Hebbeln, D., Wienberg, C., Robinson, L.F., van de Flierdt, T., Dahl, M., Douarin, M., Morrison, C., López-Correa, M., Rogers, A.D., Roberts, J.M. (submitted) Corals on the conveyor: overturning circulation and the history of a deep-sea ecosystem, Science.

Hill, A.E., Horsburgh, K.J., Garvine, R.W., Gillibrand, P.A., Slesser, G., Turrell, W.R., Adams, R.D., 1997. Observations of a Density-driven Recirculation of the Scottish Coastal Current in the Minch. Estuarine, Coastal and Shelf Science 45, 473484.

Holliday, N.P., 2003. Air-sea interaction and circulation changes in the northeast Atlantic. J. Geophys. Res. 108, 32-59.

Hovland, M., Mortensen, P.B., Brattegard, T., Strass, P., Rokengen, K., 1998. Ahermatypic coral banks off mid-Norway; evidence for a link with seepage of light hydrocarbons. PALAIOS 13, 189-200.

Howell, K.L., Holt, R., Endrino, I.s.P., Stewart, H., 2011. When the species is also a habitat: Comparing the predictively modelled distributions of Lophelia pertusa and the reef habitat it forms. Biological Conservation 144, 2656-2665.

Inall, M., Gillibrand, P., Griffiths, C., MacDougal, N., Blackwell, K., 2009. On the oceanographic variability of the North-West European Shelf to the West of Scotland. Journal of Marine Systems 77, 210-226.

Joseph, N., López Correa, M., Schönfeld, J., Rüggeberg, A. \& Freiwald, A. 2012: Sub-arctic Holocene climatic and oceanographic variability in Stjernsund, northern Norway: evidence from benthic foraminifera and stable isotopes. Boreas, 10.1111/j.1502-3885.2012.00303.x. ISSN 0300-9483. 
Kenyon, N.H., Akhmetzhanov, A.M., Wheeler, A.J., Van Weering, T.C.E., De Haas, H., Ivanov, M.K., 2003. Giant carbonate mud mounds in the southern Rockall Trough. Marine Geology 195, 5-30.

Koç, N., Jansen, E., Haflidason, H., 1993. Paleoceanographic reconstructions of surface ocean conditions in the Greenland, Iceland and Norwegian seas through the last 14 ka based on diatoms. Quaternary Science Reviews 12,115e140.

Lacan, F., Jeandel, C., 2004. Neodymium isotopic composition and rare earth element concentrations in the deep and intermediate Nordic Seas: Constraints on the Iceland Scotland Overflow Water signature. Geochemistry, Geophysics, Geosystems 5.

Lindberg, B., Bernt, C., Mienert, J., 2007. The Fugløy Reef at 70N; acoustic signature, geologic, geomorphologicand oceanographic setting. Int J Earth Sci 96, 201-213.

Lindberg, B., Mienert, J., 2005. Postglacial carbonate production by cold-water corals on the Norwegian Shelf and their role in the global carbonate budget. Geology 33, 537-540.

López Correa, M., Montagna, P., Joseph, N., Rüggeberg, A., Fietzke, J., Flögel, S., Dorschel, B., Goldstein, S.L., Wheeler, A., Freiwald, A., 2012. Preboreal onset of cold-water coral growth beyond the Arctic Circle revealed by coupled radiocarbon and U-series dating and neodymium isotopes. Quat. Sci. Rev.

Ludwig, K.R., 2003a. ISOPLOT 3.00: a geochronology toolkit for Microsoft Excel, Berkeley Geochronological Center Special Publication, Berkeley.

Ludwig, K.R., 2003b. Mathematical-Statistical Treatment of Data and Errors for ${ }^{230} \mathrm{Th} / \mathrm{U}$ Geochronology. Reviews in Mineralogy and Geochemistry 52, 631-656.

Mayewski, P.A., Rohling, E.E., Curt Stager, J., Karlén, W., Maasch, K.A., David Meeker, L., Meyerson, E.A., Gasse, F., van Kreveld, S., Holmgren, K., Lee-Thorp, J., Rosqvist, G., Rack, F., Staubwasser, M., Schneider, R.R., Steig, E.J., 2004. Holocene climate variability. Quaternary Research 62, 243-255.

McCulloch, M., Taviani, M., Montagna, P., López Correa, M., Remia, A., Mortimer, G., 2010. Proliferation and demise of deep-sea corals in the Mediterranean during the Younger Dryas. Earth and Planetary Science Letters 298, 143-152.

Mienis, F., de Stigter, H.C., White, M., Duineveld, G.C.A., De Haas, H., Van Weering, T.C.E., 2007. Hydrodynamic controls on cold-water coral growth and carbonate-mound development at the SW and SE Rockall Trough Margin, NE Atlantic Ocean. Deep-Sea Research I 54, 1655-1674.

Mienis, F., van der Land, C., de Stigter, H.C., van de Vorstenbosch, M., de Haas, H., Richter, T., van Weering, T.C.E., 2009. Sediment accumulation on a cold-water carbonate mound at the Southwest Rockall Trough margin. Marine Geology 265, 4050 .

Mikkelsen, N., Erlenkeuser, H., Killingley, J.S., Berger, W.H., 1982. Norwegian corals: radiocarbon and stable isotopes in Lophelia pertusa. Boreas 11, 163-171.

Orejas, C., Gori, A., Gili, J., 2008. Growth rates of live Lophelia pertusaand Madrepora oculata; from the Mediterranean Sea maintained in aquaria. Coral Reefs $27,255-255$. 
Piepgras, D.J., Wasserburg, G.J., 1987. Rare earth element transport in the western North Atlantic inferred from Nd isotopic observations. Geochimica et Cosmochimica Acta 51, 1257-1271.

Pirlet, H., Colin, C., Thierens, M., Latruwe, K., Van Rooij, D., Foubert, A., Frank, N., Blamart, D., Huvenne, V.A.I., Swennen, R., Vanhaecke,F.,Henriet, J.-P., 2011. The importance of the terrigenous fraction within a cold-water coral mound: A case study. Marine Geology 282, 13-25.

Reimer, P.J., Baillie, M.G.L., Bard, E., Bayliss, A., Beck, J.W., Blackwell, P.G., Ramsey, C.B., Buck, C.E., Burr, G.S., Edwards, R.L., Friedrich, M., Grootes, P.M., Guilderson, T.P., Hajdas, I., Heaton, T.J., Hogg, A.G., Hughen, K.A., Kaiser, K.F., Kromer, B., McCormac, F.G., Manning, S.W., Reimer, R.W., Richards, D.A., Southon, J.R., Talamo, S., Turney, C.S.M., van der Plicht, J., Weyhenmeyer, C.E., 2009. IntCa109 and Marine09 radiocarbon age calibration curves, $0-50,000$ years cal BP. Radiocarbon 5 1111-1150.

Roberts, J.M., Brown, C.J., Long, D., Bates, C.R., 2005. Acoustic mapping using a multibeam echosounder reveals cold-water coral reefs and surrounding habitats. Coral Reefs 24, 654-669.

Roberts, J.M., Wheeler, A.J., Freiwald, A., 2006. Reefs of the Deep: The Biology and Geology of Cold-Water Coral Ecosystems. Science 312, 543-546.

Roberts, J.M., Wheeler, A.J., Freiwald, A., Cairns, S., 2009. Cold-Water Corals The Biology and Geology of Deep-sea Coral Habitats. Cambridge Univeristy Press.

Robinson, L.F., Belshaw, N.S., Henderson, G.M., 2004. U and Th concentrations and isotope ratios in modern carbonates and waters from the Bahamas. Geochim. Cosmochim Acta 68, 1777-1789.

Rüggeberg, A., Dullo, C., Dorschel, B., Hebbeln, D., 2007. Environmental changes and growth history of a cold-water carbonate mound (Propeller Mound, Porcupine Seabight). Int J Earth Sci 96, 57-72.

Schröder-Ritzrau, A., Freiwald, A., Mangini, A., 2005. U/Th-dating of deep-water corals from the estern North Atlantic and the western Mediterranean Sea. Cold-water Corals and Ecosystems, Springer-Verlag Berlin Heidelberg, 157-172.

Schröder-Ritzrau, A., Mangini, A., Lomitschka, M., 2003. Deep-sea corals evidence periodic reduced ventilation in the North Atlantic during the LGM/Holocene transition. Earth and Planetary Science Letters 216, 399-410.

Slota, P., Jull, A., Linick, T., Toolin, L., 1987. Preparation of small samples for 14C accelerator targets by catalytic reduction of CO. Radiocarbon 29, 303-306.

Stenseth, N.C., Ottersen, G., Hurrell, J.W., Mysterud, A., Lima, M., Chan, K.S., Yoccoz, N.G., Ã...dlandsvik, B.r., 2003. Review article. Studying climate effects on ecology through the use of climate indices: the North Atlantic Oscillation, El Nino Southern Oscillation and beyond. Proceedings of the Royal Society of London. Series B: Biological Sciences 270, 2087-2096.

Stewart, H.A., Gatliff, R.W., 2008. Preliminary geological results of sea-bed sampling in the Hebrides area from the RRS James Cook in 2007. Internal report IR/08/004.

Thornalley, D.J.R., Elderfield, H., McCave, I.N., 2009. Holocene oscillations in temperature and salinity of the surface subpolar North Atlantic. Nature 457, 711-714. 
Wheeler, A.J., Beyer, A., Freiwald, A., de Hass, H., Huvenne, V.A.I., Kozachenko, M., Olu-Le Roy, K., Opderbecke, J., 2007. Morphology and environment of coldwater coral carbonate mounds on the NW European margin. Int J Earth Sci 96, 37-56.

White, M., 2007. Benthic dynamics at the carbonate mound regions of the Porcupine Sea Bight continental margin. Int. J. Earth Sci (Geol Rundsch) 96, 1-9.

White, M., Mohm, C., De Stigter, H.C., Mottram, G., 2005. Deep-water coral development as a function of hydrodynamics and surface productivity around the submarine banks of the Rockall Trough, NE Atlantic. Cold-water Corals and Ecosystems. Spinger-Verlag Berlin Heidelberg, 503-514.

Wienberg, C., Frank, N., Mertens, K.N., Stuut, J.-B., Marchant, M., Fietzke, J., Mienis, F., Hebbeln, D., 2010. Glacial cold-water coral growth in the Gulf of Cádiz: Implications of increased palaeo-productivity. Earth and Planetary Science Letters 298, 405-416.

Wienberg, C., Hebbeln, D., Fink, H.G., Mienis, F., Dorschel, B., Vertino, A., Lopez Correa, M., Freiwald, A., 2009. Scleractinian cold-water corals in the Gulf of Cádiz: First clues about their spatial and temporal distribution. Deep Sea Research Part I: Oceanographic Research Papers 56, 1873-1893. 